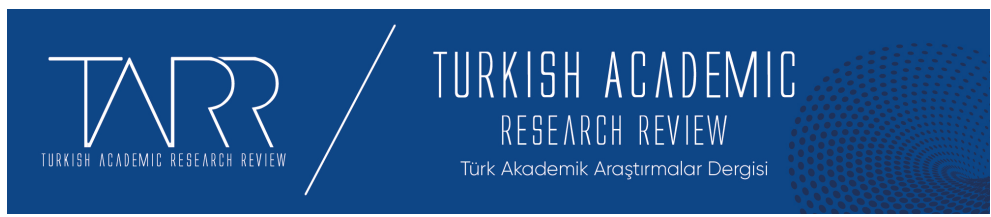

e-ISSN: 2602-2923

Yıl/Year: 2020 Cilt/Volume: 5 Sayı/Issue: 3

\title{
Aliya İzzetbegoviç’e Göre Bireyin ve Toplumun Eğitiminde Kadının Rolü
}

The Role of Women in the Education of Individual and Society According to Alija Izetbegovic

\section{Şeref Göküş - Bülent Koçoğlu - Rıfat Atay}

Dr. Öğr. Üyesi, Akdeniz Üniversitesi, İlahiyat Fakültesi, Din Eğitimi ABD, serefgokus@akdeniz.edu.tr, Orcid: 0000-0003-3322-0723.

Doktorant, Akdeniz Üniversitesi, Sosyal Bilimler Enstitüsü, Felsefe ve Din Bilimleri ABD, bulentkocoglu23@gmail.com, Orcid: 0000-0002-1244-7526.

Prof. Dr., Akdeniz Üniversitesi, İlahiyat Fakültesi, Din Felsefesi ABD, rifatay@akdeniz.edu.tr, Orcid: 0000-0001-8715-3023.

\begin{tabular}{r|l} 
Makale Bilgisi & Article Information \\
Makale Türü - Article Type & Araştırma Makalesi / Research Article \\
Geliş Tarihi - Date Received & 15 Ağustos / August 2020 \\
Kabul Tarihi - Date Accepted & 25 Eylül / September 2020 \\
Yayın Tarihi - Date Published & 30 Eylül / September 2020 \\
Yayın Sezonu & Temmuz - Ağustos - Eylül \\
Pub Date Season & July - August - September
\end{tabular}

Atıf / Cite as: Göküş, Şeref-Koçoğlu, Bülent-Atay, Rıfat, Aliya İzzetbegoviç’e Göre Bireyin ve Toplumun Eğitiminde Kadının Rolü/ The Role of Women in the Education of Individual and Society According to Alija Izetbegovic. tarr: Turkish Academic Research Review, 5 (3), 325-357. doi: tarr.782680

Intihal / Plagiarism: Bu makale, en az iki hakem tarafindan incelenmiş ve intihal içermediği teyit edilmiștir. / This article has been reviewed by at least two referees and confirmed to include no plagiarism. https://dergipark.org.tr/tr/pub/tarr

Copyright (C) Published by Mehmet ŞAHIN Since 2016- Akdeniz University, Faculty of Theology, Antalya, 07058 Turkey. All rights reserved.

Turkish Academic Research Review - Türk Akademik Araştırmalar Dergisi 


\title{
Aliya İzzetbegoviç'e Göre Bireyin ve Toplumun Eğitiminde Kadının Rolï ${ }^{1}$
}

\author{
Şeref Göküş - Bülent Koçoğlu - Rıfat Atay
}

\begin{abstract}
Özet
Bu çalışmanın amacı; Aliya İzzetbegoviç'in düşünce dünyasındaki bireyin ve toplumun eğitiminde kadınların ne tür roller üstlenebileceğini incelemektir. Doküman analizi yöntemine göre hazırlanan bu çalışmada şu sonuçlara ulaşılmıştır: Aliya, düşünce dünyasında ve yaşamında kadına özel bir anlam yükler. Onları yaratılışları itibariyle bedensel ve duygusal yönleriyle bir şahsiyet olarak anlamaya çalışırken toplumsal yönleriyle de bulundukları ve bulunmalarını arzu ettiği yerleri izah etmek için çaba sarf eder. Aliya'nın kadınlara ve aileye karşı nasıl bir tutum içerisinde olduğu her şeyden önce kendi ailesindeki kadınlarla olan diyaloğunda görülebilir. Batı'da kadınların, annenin ve olgusal olarak ailenin durumu onurlu mecrasından çıkartılarak bireysel ve toplumsal sorunların temel sebebi haline getirilir. Müslümanların dünyasında da kadınlara dair sorunlar vardır. Bu sorunlar birçok konuda olduğu gibi İslam'ın güncel hayata yön verme gücünün zayıflatılmasından kaynaklanan sorunlara benzemektedir. Aliya açısından İslamî bir doğuşla birlikte bireysel ve toplumsal bir dönüşüm için kadınların eğitilmesi ve eğitimli kadınların bu süreçte görev almaları eğitim ve din eğitimi yönüyle büyük bir önem arz etmektedir.
\end{abstract} Eğitimi.

Anahtar Kelimeler: Aliya İzzetbegoviç, Kadın, Aile, İslam, Batı, Din

\section{The Role of Women in the Education of Individual and Society According to Alija Izetbegovic}

\begin{abstract}
The aim of this study is to examine what kind of roles women can play in the education of the individual and society in Alija Izetbegovic's world of thought. In this study, prepared according to the method of document analysis, the following results were obtained: Alija ascribes a special meaning for women in his world of thought and life. While trying to understand them as a personality, both physically and emotionally, in terms of their creation, he endeavors to explain where they are and where they should be found with their social aspects. The attitude of Alija towards women and the family can be seen above all in his dialogue with the women in his family. According to him, the situation of women, mother and factual family in the West is removed from the dignified status, making it the main cause of individual and social problems. Unfortunately, there are also problems with women in the Islamic world. These problems are similar to those caused by the weakening of Islam's power to direct daily life, as in many other issues. For Aliya, the education

${ }^{1}$ Bu makale; “Aliya İzzetbegoviç'in Eğitim, Din Eğitim ve Öğretimi Görüşleri” adlı Yüksek Lisans çalışmasından yararlanılarak hazırlanmıştır.
\end{abstract}

Turkish Academic Research Review - Türk Akademik Araştırmalar Dergisi 
of women and the participation of educated women in this process is of great importance in terms of education and religious education for an individual and social transformation with an Islamic birth. Education.

Keywords: Alija Izetbegovic, Woman, Family, Islam, West, Religious

\section{Giriş}

Aliya İzzetbegoviç 8 Ağustos 1925 yılında Bosanski Samac'da dünyaya gelir. ${ }^{2}$ Babaannesi Üsküdarlı bir Türk kızıdır. ${ }^{3}$ Liseyi tüm Bosna'da ayrıcalıklı bir yeri olan Saraybosna'nın en iyi okulunda okur. ${ }^{4}$ Lise yıllarında merkezi Yugoslavya olan ancak Müslüman Boşnakların bulunduğu ülkelerde de teşkilatlanan Genç Müslümanlar Hareketine üye olur. ${ }^{5} 21$ yaşındayken II. Dünya Savaşı sonrası komünist Tito yönetimi tarafindan 14 arkadaşıyla birlikte tutuklanır ve 36 ay (19461949) hapse mahkûm edilir. ${ }^{6}$ Liseyi bitirdiği yıl 18 yaşında iken Halida Hanım'la tanışır ve 1949 yılında hapishaneden çıktıktan hemen sonra evlenir. ${ }^{7}$ Üniversite eğitimi için ilk önce Ziraat Fakültesine kaydolur ancak bitirmeden ayrılır ve 1954 yılında Hukuk Fakültesine geçiş yapar. 1956 yılında avukat olarak mezun olduğunda bir erkek ve iki kız evladı olan bir babadır. ${ }^{8}$ Daha sonra tutuklanmasına sebep olan 1969 yılında yazımına başladığı ve 1970 yılında tamamladığı 40 sayfalık "İslam Deklarasyonu" adlı eserini kitaplaştırır.9 1983 yılında tekrar cezaevine konulur ve toplamda beş yıl sekiz aylık mahkûmiyetinin ardından 25 Kasım 1988 tarihinde serbest bırakılır. ${ }^{10}$ Bir yönetim biçimi olarak tercih edilen komünizm yirminci yüzyılın sonuna doğru tüm dünyada olduğu gibi Yugoslavya'da da çöküşs sürecine girerken tarihi derinliği olan Hırvat ve Sırp milliyetçiliği tekrar ortaya çıkmaya başlar. Bütün bunlar yaşanırken Aliya, cezaevinde olmasına rağmen bu gelişmelerden haberdar olur ve tarihte yaşananların tekrarlanmaması için Müslüman Boşnakların haklarını korumak adına bir parti kurmaya karar verir. ${ }^{11} \mathrm{O}$ ve arkadaşları "fakir halkın partisi"12 olarak tarif ettikleri Demokratik Eylem Partisini 1989 Kasım ayında kurarlar. Demokratik Eylem Partisi her ne kadar Müslümanların

2 Aliya İzzetbegoviç, Tarihe Tanıklı̆̆ım, Trc. Alev Erkilet vd., 16. Bsk. (İstanbul: Klasik Yayınevi, 2016), 11.

${ }^{3}$ Hüseyin Yorulmaz, "İzzetbegoviç Ailesinin Bilinmeyenleri”, Hece Aylık Edebiyat Dergisi, S.229, (2016), 89.

${ }^{4}$ Hüseyin Yorulmaz, Bilge Lider Aliya İzzetbegoviç, (İstanbul: Hat Yayınları, 2015), 40.

5 Rahman Ademi-Mustafa Orçan, "İzzetbegoviç'in Hapishane Arkadaşı ve Dostu Hasan Çengiç’le Konuşma”, Hece Aylık Edebiyat Dergisi, Çev. Cenana Braçkoviç, S.229, (2016), 26; Cemile Halilovic Tekin, "Boşnaklar'ın Bosna-Hersek Devleti'ni Kurma Mücadelesi ve Alıja Izetbegovıc", Türk- İslam Medeniyeti Akademik Araştırmalar Dergisi, S.14, (2012), 175; http://www.mm.co.ba/index.php/tr/oezgecmisleri/879-bilge-kral-hayata-goezleriniyumdu (Erişim: 05.05.2020).

${ }^{6}$ Aliya İzzetbegoviç, Kendi Kaleminden Aliya İzzetbegoviç: II. Endülüs Soykırımına Geçit Vermeyen Bilge Adam, Trc. Alev Erkilet vd., (İstanbul: Dergâh Ofset Yayınları, 2003), 25.

7 Zehrudin İsakoviç, "Aliya İzzetbegoviç 1925-2003 Biyografi”, Hece Aylık Edebiyat Dergisi, S.229, (2016), 152; İzzetbegoviç, Tarihe Tanıklığım, 23.

8 İzzetbegoviç, Tarihe Tanıklı̆̆ım, 29.

9 Yorulmaz, Bilge Lider Aliya İzzetbegoviç, 110; İzzetbegoviç, Tarihe Tanıklı̆̆ım, 29-30.

10 Hacer Öztürk, "Yıldızın Altında Yatan Adam", Hece Aylık Edebiyat Dergisi, S. 229, (2016), 722-723; İzzetbegoviç, Tarihe Tanıklı̆ım, 66.

${ }_{11}$ R. İhsan Eliaçı, Aliya İzzetbegoviç Yenilikçi Müslüman Düşünürler Dizisi 2, 2. Bsk., (İstanbul: Tekin Yayınevi, 2016), 62-63.

12 Aliya İzzetbegoviç, Köle Olmayacağız, Trc. Rahman Ademi, 27. Bsk., (İstanbul: Fide Yayınlar1, 2017), 55.

Turkish Academic Research Review - Türk Akademik Araştırmalar Dergisi 
kurduğu bir siyasal oluşum olsa da parti programını ve amacını kabul eden tüm Bosna vatandaşlarının birliğini ve çıkarlarını korumayı hedefler. ${ }^{13} 1990$ yılında diğer federasyonlarda olduğu gibi Bosna Hersek'te de seçim yapılır ve bu seçim sonucunda kurulan koalisyon hükümetinin cumhurbaşkanlığına Aliya İzzetbegoviç getirilir. ${ }^{14}$ Demokratik Eylem Partisi, bu seçimde, oyların \%38'ini alır ve 86 milletvekili çıkarır. ${ }^{15}$

Bosna Hersek'te 29 Şubat-1 Mart 1992 tarihlerinde halkın \%63,4'ünün katıldığı bir referandum düzenlenir. Sonuç olarak \%99,43'lük bir oranla bağımsızlık yönünde "evet" oyu kullanılır. ${ }^{16}$ Referandum neticesinde Bosna Hersek bağımsızlığını ilan eder, önce 6 Nisan 1992'de Avrupa Topluluğu, bir gün sonra ise Amerika Birleşik Devletleri, Bosna Hersek'i bağımsız bir devlet olarak tanır. Bağımsızlık sonrası, ülkede büyük bir etnik temizliğe dönüşecek olan savaş, eski Yugoslavya Devleti'nin silahlandırdığı Bosnalı Sırplar tarafindan başlatılır. ${ }^{17}$ Tüm dünyanın gözleri önünde, Avrupa'nın tam ortasında 3,5 yıl süren ve birçok katliamın yapıldığı savaş, 1995 yılında imzalanan Dayton Barış Antlaşması ile sona erer. ${ }^{18}$ Aliya, savaş sonrası 1996 ve 1998 yıllarında yapılan her iki seçimde de oyların çoğunluğunu alarak cumhurbaşkanlığı görevine devam eder. ${ }^{19} 12$ Ekim 2000 tarihinde sağlık sorunlarını gerekçe gösterip ertelediği istifa kararını ilan ederek görevini bırakır. 19 Ekim 2003 tarihinde vefat eder. ${ }^{20}$ Sıkıntılarla geçen hayatını kendisi şu ifadelerle özetler: "Bana tekrar yeni bir hayat yaşama firsatı sunulsaydı kabul etmezdim. Ancak, eğer yeniden doğsaydım yine kendi hayatımı yaşamayı seçerdim." 21

Aliya İzzetbegoviç, herkes gibi normal, sıradan bir insandır ve aynı zamanda kelimenin tam anlamıyla sade bir Müslümandır. Hayatının farklı evrelerinde böyle düşündüğüne ve böyle olduğuna dair birçok cümlesi, tavrı ve eylemi söz konusudur. Halkı tarafından çok sevilen birisi olarak şahsını "ulusun babası" diye vasıflandırmaya çalışanlara otokrasi ve diktatörlük kokan bu tabirden dolayı duyduğu rahatsızlığını ifade eder. ${ }^{22}$ Kendisini ve liderlik anlayışını nasıl tanımladığı Hz. Peygamber hakkında kullandığı şu ifadelerden rahatlıkla anlaşılabilir: "Muhammed (as) güzeldi fakat manken değildi. İyi idi fakat enayi değildi. Cesurdu

13 İsakoviç, “Aliya İzzetbegoviç 1925-2003 Biyografi”, 162-164.

14 Tunç Pulat, "Bosna-Hersek’te Devlet İnşa Süreci: 1996-2013 Dayton Antlaşması Sonrasında Bosna-Hersek", (Yayımlanmamış Yüksek Lisans Tezi, Atılım Üniversitesi Sosyal Bilimler Enstitüsü, Ankara: 2015), 15-16.

${ }^{15}$ Zümrüt Gümüş, "Bosna Hersek Savaşı ve Uluslararası İlişkilerdeki Yeri”, (Yayımlanmamış Yüksek Lisans Tezi, Cumhuriyet Üniversitesi Sosyal Bilimler Enstitüsü, Sivas: 2005), 49-50.

$16 \mathrm{O}$ dönemde Bosna nüfusunun \%52'si Müslüman, \%30'u Sırp, \%17'si Hırvat ve \%1'i de diğer etnik unsurlardan ibarettir. Detaylı bilgi için bk. Mustafa Balcı, "İzzetbegoviç'in Dostu Fatih Ali Hasaneyn ile Konuşma", Trc. Elvan Büşra Yenigün, Hece Ayllk Edebiyat Dergisi, S.229, (2016), 613-614; Tahir Kodal, "Bosna-Hersek'in Bağımsızlığını Kazanması ve Türkiye (1990-1992)", Atatürk Araştırma Merkezi Dergisi, 34/2, (2018), 426.

${ }^{17} \mathrm{https}: / /$ www.aa.com.tr/tr/dunya/bosna-hersek-bagimsizlik-gununu-kutluyor/178309 (Erișim: 15.05.2020).

18 Yasin Safak, "Bosna Savaşı ve Yugoslavya'nın Parçalanması”, (Yayımlanmamıș Yüksek Lisans Tezi, Kadir Has Üniversitesi Sosyal Bilimler Enstitüsü, İstanbul: 2010), 124.

19 Tekin, "Boşnaklar'ın Bosna-Hersek Devleti'ni Kurma Mücadelesi ve Alija Izetbegovıc", 183.

20 Mehmet Ataş, "Entelektüel Lider Bağlamında Aliya İzzetbegoviç Üzerine Nitel Bir Inceleme”, (Yayımlanmamış Yüksek Lisans Tezi, Sakarya Üniversitesi Sosyal Bilimler Enstitüsü, Sakarya: 2016), 73

21 İsakoviç, “Aliya İzzetbegoviç 1925-2003 Biyografi”, 194.

22 İzzetbegoviç, Kendi Kaleminden Aliya İzzetbegoviç: II. Endülüs Soykırımına Geçit Vermeyen Bilge Adam, 280.

Turkish Academic Research Review - Türk Akademik Araştırmalar Dergisi 
fakat acımasız değildi. Akıllı idi fakat filozof değildi. Basiretli, fakat hayalperest değildi. Israrcı idi fakat inatçı değildi. Bilge fakat ukala değildi." ${ }^{23} \mathrm{Bu}$ örnekler, kendisi de dahil olmak üzere bazı insanların kutsanmasından ve onlara Tanrısal özellikler yüklenmesinden hoşlanmadığını gösterir. Bu yaklaşımı Müslümanlar için önemli bir örneklik teşkil eder. Aliya'nın komutanlarından Şerif Petkoviç ile yapılan bir söyleşide yapılan şu iki vurgu önemlidir: 1-“Bosna'da liderler sevilir ama asla kutsal değildir." 2-“Sık sık Türkiye'ye gittiğim için Türkiye'de Aliya'ya bazı çevrelerin "bilge kral" dediğini biliyorum. Bosna'da "bilge kral" derseniz bunun bir karşıllğını bulamazsınız." 24

Farklı etnik ve dinî topluluklarla eşit seviyede birlikte yaşama arzusu, tevazuu, iktidar imkânlarını şahsi çıkarları için kullanmaması, gösterişten uzak liderliği ve otoriterliği reddi, sadece Müslümanlar için değil, Batı için de önemli bir numunedir. ${ }^{25}$ Kendisi bile isteye böyle olmak ve böyle kalmak istemesine rağmen ona dair yazılanlarda; kimisi normalin içinde kalırken kimisi de konusu gereği veya mevcut anlayışıyla kendisine uygunlaştırarak onu farklı ifadelerle anlatır, hatta yüceltir. Onu, istemediği, sevmediği sıfatlarla, simgelerle sunmaya çalışır. Her makalenin, tezin, araştırmanın veya köşe yazısının giriş cümleleri bu tür tanımlamalara ayrılır. Son dönem yazılanların bazıları da ona dair yapılan tarifleri, verilen sıfatları toparlayarak bütünüyle veya yazıda bir bölüm halinde yapılan bu tanım ve atfedilen bu sıfatların yanlışlı̆ıını anlatmaya konu edinir. Yapılan tanımlamalar arasında en çok eleştiri alanı "bilge kral" tamlamasındaki "kral" ifadesidir. ${ }^{26}$ Buna rağmen "bilge kral" ifadesi makale, tez, sempozyum bildirisi gibi çalışmalarda fazlaca kullanılmaktadır. ${ }^{27}$ Bunun dışında en çok ve sık kullanılan;

23 Aliya İzzetbegoviç, İslami Yeniden Doğuşun Sorunlarl, Trc. Rahman Âdemi, 32. Bsk., (İstanbul: Fide Yayınları, 2017), 164; Abdullah Soysal, "Entelektüel Liderliği ile Model İnsan: Aliya İzzetbegoviç", Uluslararası İslam ve Model İnsan Sempozyumu (26-27 Nisan 2018), Ed. M. Akif Özdoğan vd., (Kahramanmaraş: Kahramanmaraş Büyükşehir Belediyesi Yayınları, 2018), 89.

24 https://www.dunyabizim.com/soylesi/serif-petkovic-ile-aliya-izzetbegovice-dair-konustukh24995.html (Erişim: 17.05.2020).

${ }_{25}$ Mustafa Orçan, "Ufuk Soran ile Bir Bosna Gazisinin İlginç Anıları", Hece Aylık Edebiyat Dergisi, S.229, (2016), 658-660.

${ }^{26}$ Detaylı bilgi için bk. Yalçın Çetin, "Bilge Kral" ve "Müslüman Batı Aydını" Şeklinde Yaratılmış İmajların Aliya İzzetbegoviç' in Eserleri, Kişiliği ve Yaşantısı Üzerinden Geçerliliğinin Kavramsal Soruşturması Üzerine”, 5.Uluslararası Kültür ve Medeniyet Kongresi Tam Metin Kitabı (12-14 Nisan 2019), Ed. Sedat Cereci- Nurlan Akhmetov, (Hatay: İksad Puplication, 2019), 216; Cihan Aktaş, "Sadece Aliya", https://www.dunyabulteni.net/kultur-sanat/sadece-aliya-h337468.html (Erişim: 01.05.2020); Ümit Aktaş, "Doğu ve Batı Arasında Mücahid Bir Bilge: Aliya İzzetbegoviç (1925-2003)", https://adaletzemini.org/19-kasim-2017-dogu-ve-bati-arasinda-mucahid-bir-bilge-aliya-

izzetbegovic-1925-2003/ (Erişim: 01.05.2020); Ümit Aktaş, Çă̆ımızın Tanıkları, 2. Bsk., (İstanbul: Metamorfoz Yayincilik, 2014), 7.

27 Detaylı bilgi için bk. Yasin Aktay, "Açılış Konuşması", Uluslararası Aliya İzzetbegoviç Seтроzуити (11-12 Ekim 2008), Ed. Ömer Hakan Özalp-Kenan Gültürk, (İstanbul: Etkin Ajans, 2010), 29; Muharrem Sevil, "Kadeh Bağını Kıran "Dedo", Uluslararası Aliya İzetbegoviç Sempozyumu (11-12 Ekim 2008), Ed. Ömer Hakan Özalp-Kenan Gültürk, (İstanbul: Etkin Ajans, 2010), 42; Niyazi Öztürk, "Nurettin Topçu ve Aliya İzzetbegoviç’te Din Anlayışı", (Yayımlanmamış Yüksek Lisans Tezi, Tokat Gaziosmanpaşa Üniversitesi Sosyal Bilimler Enstitüsü, Tokat: 2019), 47; Aynur Limon, "Siyasi Bir Lider Olarak Aliya İzzetbegoviç", (Yayımlanmamış Yüksek Lisans Tezi, Afyon Kocatepe Üniversitesi Sosyal Bilimler Enstitüsü, Afyonkarahisar: 2019), V; Musab Akçay, "Aliya İzzetbegoviç ve Düşünce Dünyası", (Yayımlanmamış Yüksek Lisans Tezi, Atatürk Üniversitesi Sosyal Bilimler Enstitüsü, Erzurum: 2016), 18; Mahmut Hakkı Akın, "Aliya İzzetbegoviç’in Entelektüel Mirası", Uluslararası Aliya İzzetbegoviç Sempozyumu (11-12 Ekim 2008), Ed. Ömer Hakan Özalp-Kenan Gültürk, (İstanbul: Etkin Ajans, 2010), 101; Emre Ş. Aslan, Özgür Selvi, "Bir

Turkish Academic Research Review - Türk Akademik Araştırmalar Dergisi 
entelektüel, düşünür, bilge, aydın, fikir adamı, eylem adamı, dava adamı, ahlak adamı, şuurlu bir Müslüman, ordu komutanı, siyasi parti lideri, devlet başkanı tanımlamalarıdır. ${ }^{28}$ Bize göre Aliya düşünen, düşündüğünü yazan, yazdığını yaşayan bir şahıstır. Yerelden evrensele, bireyden topluma sorunları tartışıp çözüm üreten ve ürettiği çözümleri her seviyede, ortamda ve konumda -ki buna devlet başkanlığ dahil- uygulama imkânı bulan özgün bir şahsiyettir. Aliya İzzetbegoviç halkı tarafından sevilen bir liderdir. Bosna savaşında direnme ruhunun oluşmasındaki en temel unsur; tüm insanların imkânsızlıklara rağmen ona duydukları sevgiden dolayı özgür iradeleri ile peşinden zorlanmaksızın gitmeleridir. ${ }^{29}$

Aliya İzzetbegoviç, gençlik yıllarından itibaren yaptığı okumalarından ve çok yönlü hayat tecrübesinden elde ettiği birikimle birçok eser kaleme alır. Bu eserler sayesinde onun fikir dünyası ve düşünceleri öğrenilebildiği gibi Bosna'nın yakın tarihi, bireysel ve toplumsal ilişkiler, savaş yılları ve buna bağlı olan uluslararası ilişkiler, hem Batılı ülkeler hem de İslam ülkeleri, gibi birçok konu hakkında da objektif bilgiler elde edilebilir. Bu bağlamda araştırmada, Aliya İzzetbegoviç açısından bireyin ve toplumun inşasında kadınların nasıl bir rolü olduğu sorusuna cevap aranmaya çalışılacaktır. Konuyu farklı yönleriyle tahlil edebilmek için makale başlığı altında sıralı ve birbirini açıklayan şu alt başlıklarla incelemeye devam edilecektir; kadinlar,

1. Doğumundan ölümüne Aliya'nın şahsiyetinin oluşumuna etki eden

2. Batı' da kadın ve aile anlayışı,

3. İslam dünyasında kadın ve aile anlayışı,

4. Eğitimli bir kadının iyi bir bireyin ve toplumun oluşumundaki rolü.

$\mathrm{Bu}$ çalışmada; nitel araştırma yöntemlerin biri olan doküman analizi tercih edilmiştir. Nitel araştırmalar, incelenen konu gereği insanların tutum, davranış, görüş ve deneyimlerini daha teferruatlı bir yaklaşımla anlama, yorumlama ve betimleme yönünde derinlemesine ortaya konan çaba olarak ifade edilmektedir. Nitel araştırmalar daha çok anlamaya dönük olarak yapılan, "nasıl, niçin" gibi sorulara cevapların arandığı incelemelerdir. Ulaşılan tüm belgelerin incelendiği doküman analizi ise, yazılı belgelerin tamamını titizlikle ve sistematik olarak analiz etmenin yöntemi olarak isimlendirilir. Aynı zamanda inceleme sonucunda anlam çıkarmak, ilgili konu hakkında bir anlayış oluşturmak ve verilerin incelenmesinin

Marka Kişilik Olarak Aliya İzzetbegoviç’in Türk Toplumundaki Algısı”, I. Uluslararası Bir Bilge Bir Ülke Sempozyumu Bildiriler Kitabı (3-5 Ekim 2018), Ed. Mümin Hakkığlu vd., (Gümüşhane: Gümüşhane Üniversitesi Yayınları, 2018), 227; Hamza Aktaş, "Aliya İzzetbegoviç'in Düşüncesinde Ahlak-Terbiye İlișkisi”, I. Uluslararası Bir Bilge Bir Ülke Sempozyumu Bildiriler Kitabı (3-5 Ekim 2018), Ed. Mümin Hakkığlu vd., (Gümüşhane: Gümüşhane Üniversitesi Yayınları, 2018), 301; İlbey Dölek, "Aliya İzzetbegoviç'in Eserlerinde Batı, Hristiyanlık ve Hz. İsa”, Uluslararası Mardin Artuklu Multidisipliner Çalışmalar Kongresi Sosyal Bilimler Tam Metin Kitabı (19-21 Nisan 2019), Ed. Hasan Çiftçi, Yasemin Ağaoğlu, (Mardin: İksad Yayınevi, 2019), 449.

${ }^{28}$ Aykut Aygün, "Aliya İzzetbegoviç’te Din ve Siyaset", (Yayımlanmamıș Yüksek Lisans Tezi, Necmettin Erbakan Üniversitesi Sosyal Bilimler Enstitüsü, Konya: 2017), 1-2; Meryem Bayram, "Aliya İzzetbegoviç’in İslamlaşma Anlayıșı", (Yayımlanmamıș Yüksek Lisans Tezi, Necmettin Erbakan Üniversitesi Sosyal Bilimler Enstitüsü, Konya: 2019), 1-2; Musa Özdemir, "Aliya İzzetbegoviç Düşüncesinde Üçüncü Yol Kavramı ve Felsefi Temelleri”, (Yayımlanmamış Yüksek Lisans Tezi, Gazi Üniversitesi Sosyal Bilimler Enstitüsü, Ankara: 2014), 5.

${ }^{29}$ Soysal, "Entelektüel Liderliği ile Model İnsan: Aliya İzzetbegoviç”, 88.

Turkish Academic Research Review - Türk Akademik Araştırmalar Dergisi 
ardından yorumlama yapmak da doküman analizi yöntemi açısından bir gerekliliktir. ${ }^{30} \mathrm{Bu}$ kapsamda araştırmada; Aliya'nın kendi eserleriyle birlikte hakkında yazılmış olan kitaplar, farklı yönlerini inceleyen tez, makale, bildiri ve dijital materyaller ele alınarak mevcut literatür çerçevesinde sınırlandırılmış konu hakkında derinlemesine inceleme, analiz ve yorumlar yapılacaktır.

\section{Doğumundan Ölümüne Aliya'nın Şahsiyetinin Oluşumuna Etki Eden Kadınlar}

Aliya bir mütefekkir, lider, siyaset adamı, bir baba ve Müslüman bir birey olarak düşüncesinin temeline ve yaşam felsefesine düalist bir anlayışla yol bulan ancak tüm boyutlarıyla tevhide çıkan ilkeleri yerleştirir. Olayları, nesneleri, insanları, dinleri ve ideolojileri anlamaya, tanımlamaya çalışırken hep neden ve nasıl sorularını sorarak arkasındaki hikmeti ve sebebi anlamaya çalışır. Ona göre sebepsiz ve hikmetsiz bir varoluş söz konusu değildir. Her șey birbirine bağlı olarak ve birbirini tamamlamak üzere var olurken kadın ve erkeğin düalizmi de birbirlerine olan bağımlılıkları ve zorunlulukları itibariyle tekliğe yani tevhidin oluşmasına işaret eder. Aliya, kadınlara dair bakış açısını yaşamın içindeki pratik sorunlardan hareketle birçok yönden ele alarak açıklamaya çalışır. Bu açıklamayı; hayatında en fazla etkilendiği şahıs olarak tanımladığı annesiyle ${ }^{31}$, âşık olarak evlendiği ve sadakatle ömrünün sonuna kadar birlikte olduğu eşiyle, en zor zamanlarında bile sürekli yanında bulduğu kendisini çok seven kız çocukları ve en nihayetinde kız torunları ile olan ilişkilerinden elde ettiği tecrübelerden hareketle yapmaya çalışır.

Aliya'nın ailesi "Beyzade" ünvanlı zengin bir aile olmakla birlikte cömert ve adil olmalarıyla da meşhurdurlar. ${ }^{32}$ Bulundukları bölgede yaşayan insanlar karşılaştıkları problemlere çözüm bulmak için geçmişten tevarüsle genellikle Aliya'nın ailesine başvururlar. ${ }^{33} \mathrm{Bal}$, onun gelmiş olduğu aileyi değerlendirirken kadınların da erkekler kadar itibarı yüksek ailelerden geldiklerini ifade eder: Büyük Dede İzzet Bey'in eşi Şakira Hanım yüksek statülü bir aileden, Dede Aliya Begoviç'in eşi Sıdıka Hanımın babası Osmanlı ordusunda Belgrad'da subay olarak hekimlik yapan ve aynı zamanda bir Türk olan Cerrah ailesinden, Annesi Hiba Hanım da Osmanlı döneminde vakıflara ait gelirleri toplayan Câbiya ailesindendir. Aynı şekilde eşi Halida Hanımın da baba soyundan büyük dedeleri Mohaç Savaşında gösterdikleri yararlılıktan dolayı Kanuni Sultan Süleyman tarafından berat ve arazi verilerek ödüllendirilen Repovac ailesinden gelmiştir. Verdiği bu bilgilerle Bal, Aliya'nın bilgelik vasfına sahip olmasında ve liderlik özelliğinin oluşmasında sosyal olarak itibarı yüksek ailelerden gelmesinin de etkili olduğu değerlendirmesinde bulunur. ${ }^{34}$ Ailesinde bulunan bu düzgün duruşun oluşumunda erkekler kadar kadınların da etkisinin olduğu mutlak bir gerçektir. Ona göre "Okumamış, ihmal edilmiş ve mutsuz bir anne, Müslüman halkların yeniden doğuşunu başlatacak ve başarılı bir şekilde devam ettirecek oğul ve kızları

\footnotetext{
${ }^{30}$ Bilgen Kıral, "Nitel Bir Veri Analizi Yöntemi Olarak Doküman Analizi”, Siirt Üniversitesi Sosyal Bilimler Enstitüsü Dergisi, S.15, (2020), 172-173.

31 Yorulmaz, Bilge Lider Aliya İzzetbegoviç, 24; Yorulmaz, "İzzetbegoviç Ailesinin Bilinmeyenleri”, 90.

${ }^{32}$ Mahmut Hakkı Akın, Faruk Karaarslan, Aliya İzzetbegoviç: Özgürlük Mücadelesi ve İslâm Düşünürü, 2. Bsk., (İstanbul: Pınar Yayınları, 2015), 15-22, 26-29.

33 Yorulmaz, Bilge Lider Aliya İzzetbegoviç, 18.

34 Hüseyin Bal, "Aliya İzzetbegoviç ve Bilgeliğin Tezahürleri”, Sosyal Araştırmalar ve Davranış Bilimleri Dergisi, C.5, S.9, (2019), 369-372.
}

Turkish Academic Research Review - Türk Akademik Araştırmalar Dergisi 
büyütemez." ${ }^{35}$ Gelecek nesillerin yetiştirilmesinde annelere önemli roller atfeden Aliya tüm annelerin eğitimli olması gerektiğini dile getirir. ${ }^{36}$ Her evde temel bir role sahip olan annenin dinî açıdan bilgili ve bilinçli olması çocuğun özellikle dinî eğitimi açısından çok daha olumlu sonuçlar doğurur. "Onun sevdiği her şey bana sempatik geliyor" dediği ninesi Sıdıka Hanım çok dindar bir insan iken ${ }^{37}$ annesi Hiba Hanım da çilekeş bir kadındır. ${ }^{38}$ Annesinin tüm zorluklara rağmen göstermiş olduğu azim ve gayreti, namazdaki huşusu ve samimi duaları onda belirgin izler bırakır. ${ }^{39}$ Ölümünden bir süre önce yapılan bir söyleşide Annesi Hiba Hanım'ın kendisi üzerindeki etkisini şu cümlelerle anlatır:

"Benim ailemden aldığım İslami terbiye kişiliğimin oluşmasında daha önemliydi. Rahmetli Validem Hiba çok muttaki bir kadındı. Anneme karşı sonsuz bir sevgi besliyor, onun sevdiği her şeyi seviyordum. Annem dinini seven, İslam'1 yaşayan bir kadındı. Zaten Müslümanların kimliğini korumada sahip olduğumuz köklü aile geleneği ve aldığımız terbiyenin ne denli önemli ve belirleyici olduğu böylesi kargaşa durumlarında daha bir belli olacaktır." 40

Evliliklerin tarafların birbirini tanıması ve karşılıklı aile rızalarının alınmasıyla gerçekleşmesi daha mutlu bir yapı kurulmasına sebep olabilir. Bu yöntemle gerçekleşen evliliğe kısaca, yarı görücü usulü denilebilir. Evlilikte karşılıklı sadakat en önemli katalizördür. Aliya ile eşi Halida Hanım arasında evlilik öncesi ve sonrasındaki sürece bakıldığında göze ilk çarpan husus sadakat eksenli ve karşılıklı anlayışa dayalı güçlü bir beraberliğin varlığıdır. Eşine dair şu düşüncesi oldukça manidardır: "Ona kelimenin tam anlamıyla aşıktım ben, bunda utanıp çekinilecek bir şey yok, siz de bunu anlayabilirsiniz. Hani siz şairlerin diliyle uğrunda ölecek kadar büyük bir aşktı bizimkisi." ${ }^{41}$ Eşiyle kurduğu sevgi bağının bir benzerini çocuklarıyla da kurar. Çocuklarıyla oluşturduğu duygusal irtibatın konusu, bize onun nasıl bir eş olduğundan sonra nasıl bir baba hatta dede olduğunu anlamamızı sağlaması açısından da önemlidir. Aliya'nın küçüklüğünden itibaren ailesinden gördükleri, çocuklara verilecek dinî eğitimin baskı yapılmadan ama bilinçli ve özellikle yaşanarak verilmesi halinde aile bağlarının daha güçlü olabileceğine dair güzel örneklerdir. ${ }^{42}$ Baskı görmeden şefkatle aldığı dinî eğitimi aynı yöntemle çocuklarının terbiyesinde kullanır. Bu anlamda annesine dair şu düşüncesini aktarması önemlidir:

"Rahmetli annem çok dindar bir kadındı ve dine olan bağlılığımı -en azından kısmenona borçluyum. Sabah namazlarına hiç aksatmadan tam vaktinde kalkar ve beni de kaldırırdı ki ben de Belediye Binası'nın yakınındaki mahalle camisi olan Hadzijska Camii'ne gidebileyim." 43

35 Öztürk, "Nurettin Topçu ve Aliya İzzetbegoviç’te Din Anlayışı", 64; İzzetbegoviç, İslami Yeniden Doğuşun Sorunlarl, 59;

${ }^{36}$ Aygün, "Aliya İzzetbegoviç’te Din ve Siyaset”, 66.

37 Yorulmaz, Bilge Lider Aliya İzzetbegoviç, 24-25.

38 İsakoviç, "Aliya İzzetbegoviç 1925-2003 Biyografi”, 149.

39 Yaşar Uğurlu, "Doğu'nun Çocuğu Batı'nın Münevveri Aliya İzzetbegoviç", Hece Aylık Edebiyat Dergisi, S.229, (2016), 506; Yorulmaz, Bilge Lider Aliya İzzetbegoviç, 32-34.

40 Aliya İzzetbegoviç, Konuşmalar, Trc. Fatmanur Altun-Rıfat Ahmetoğlu, 23. Bsk., (İstanbul: Klasik Yayınları, 2017), 245.

${ }^{41}$ İbrahim Demirci, "Aliya İzzetbegoviç'in Hayatında ve Eserlerinde Aile ve Kadın”, Hece Aylık Edebiyat Dergisi, S.229, (2016), 369; İzzetbegoviç, Tarihe Tanıklı̆ı̆m, 491-492.

42 Yorulmaz, Bilge Lider Aliya İzzetbegoviç, 77-79.

43 İzzetbegoviç, Tarihe Tanıklı̆̆ım, 12; Demirci, "Aliya İzzetbegoviç'in Hayatında ve Eserlerinde Aile ve Kadın”, 368.

Turkish Academic Research Review - Türk Akademik Araştırmalar Dergisi 
Aile ortamında kendi kültürü içerisinde ve doğallı̆̆ında yaşanan bu durum, çocukları ile kendisi arasında iyi bir iletişim kurmasını sağladığı gibi çevrenin kötü etkisine karşı ailenin bütünlüğü üzerinde bir koruma kalkanı oluşturur. ${ }^{44} \mathrm{Ev}$ ortamı çocuklar açısından özgürlükçü, büyükler açısından saygı merkezli olmalıdır. ${ }^{45}$ Aile fertlerinin birlikte geçireceği zamanlar artırılmalı bunun için her türlü imkân kullanılmalıdır. Çocuklarından en büyük kızı Leyla matematik, Sabina ise dilbilim mezunu iken, oğlu Bakir de mimar olur. En büyük torunu Selma gazetecilik bölümünü okur. Aliya torunlarının hepsinin kendisinden daha iyi İngilizce konuştuğunu ifade eder. Tamamı kız olan beş torunundan ikisi kendisi ikinci defa hapse girmeden önce, diğer üçü ise hapisteyken dünyaya gözlerini açar. ${ }^{46}$

Aliya ile çocukları arasında oluşan sevgi bağının gücünü aktarmaya çalışırken çocuklarının cezaevindeki babalarına yazdığı mektuplardan vereceğimiz şu örnekler aynı zamanda bir ailede baba ile çocukları arasındaki dayanışmanın nasıl olması gerektiği konusunu anlamamıza da vesile olacaktır: Sabina, 8 Ağustos 1983 ’te yazdığı mektupta babasına üçüncü bir kız torununun dünyaya geldiğini detaylı bir şekilde anlatır. Leyla, 9 Ağustos 1983 'teki mektubuyla gördüğü rüyada babasının yüzünü avuçlayıp kendisini derin bir sevgiyle öptüğünden bahsederek hayatı boyunca hissetmediği kadar derin bir sıcaklığın kalbinde nasıl oluştuğunu yazar. Sabina, 19 Eylül 1983'teki mektubunda onsuz geçen bir bayramdan, evde yaşananlardan, annesinin yaptığı tatlıdan bahsederken sürekli onu düşündüğünü, rüyalarına girdiğini, kendisini çok özlediğini anlatırken sigarayı azaltması ve çok yürümesi gerektiğini hatırlatır. Leyla, 14 Aralık 1983'te kendisiyle yazarak da olsa sohbet etmenin azap çektiren sıkıntılardan belki biraz uzaklaştırabileceğini anlatırken o da Sabina gibi sık sık ona dair rüyalar gördüğünü ve her rüyada eve gelip kendileriyle kalıp tekrar gittiğini, aceleyle dönüp bakamadığını aslında kendisine bir defa bakma firsatı bulsa yüz yüze yapamadığı sohbeti telafi edebileceğini mektubunda özlemle hikâye eder. Bakir, 30 Aralık 1983'te onsuz geçen bir yılın daha bittiğini, bu yıl içerisinde bir kız torununun daha dünyaya geldiğini dile getirirken dışarı çıkacağı günleri düşünmesini, yine bir gün birlikte kahve içip sonrasında torunlarına elbise alabileceklerini yazar ve bununla onu teselli etmeye çalışır. Mektubunda iki haftada bir ziyaretine geleceklerini söylerken ondan kitap okumayı bırakmamasını ister. Leyla, 23 Ocak 1984'teki mektubunda "Doğu Batı Arasında İslam" adlı kitabının yayınlandığını ve tüm dünyada satışa çıktığının haberini müjdeler. Sabina, 6 Şubat 1984'te yazdığı mektubunda şu ifadeye yer verir: "Fakat bazen bana ümit veren insanlar ve hadiseler de oluyor. Beni en çok mutlu eden şey, birisinin bana "Aliya İzzetbegoviç’le bir akrabalığınız var mı? diye sorması, benim de "babam" demem. Bu o gün bana yetiyor." ${ }^{37}$ Çocukları büyük bir gayretle evde, çevrede ve dünyada genel olarak neler olup bittiğini onunla irtibatta kalıp ona özetleyerek bilgilendirme yaparlar. Sabina her gün zihninde kendisine sayısız mektup yazdığını, oturup yazmaya başladığında ise daha önce nelerden bahsettiğini unuttuğunu anlatır. Ona her şeyden söz etmek istediğini söylerken evde yaşanan en ufak bir olaydan bile haberdar olmasını arzu ederek onu canlı tutmaya,

44 Faruk Karaarslan, "Entelektüel Üzerine Bir Çalışma: Aliya İzzetbegoviç Örneği”, (Yayımlanmamış Yüksek Lisans Tezi, Selçuk Üniversitesi Sosyal Bilimler Enstitüsü, Konya: 2010), 45.

45 Yorulmaz, Bilge Lider Aliya İzzetbegoviç, 75-77.

46 İzzetbegoviç, Tarihe Tanıklı̆̆ım, 492.

${ }^{47} \mathrm{Bal}$, “Aliya İzzetbegoviç ve Bilgeliğin Tezahürleri”, 366.

Turkish Academic Research Review - Türk Akademik Araştırmalar Dergisi 
kendileri ile zihin aleminde birlikte/hemhal olmaya davet eder. ${ }^{48}$ Çocuklarının ortaya koyduğu bu gayret babalarına direnme gücü verir. Yapılan bu dayanışma onu canlı ve zinde tutmakla birlikte bir gün özgürlüğe kavuşacağının umuduyla dolmasını ve rahatlamasını sağlar. Aliya, bu durumu teyit ederek cezaevi şartlarında salim bir ruh halini muhafaza etmesine güçlü imanını ve ailesini sebep gösterir: "Bunu, genel olarak itikadıma ve çocuklarımın sadakatine ve moral desteğine borçluyum." ${ }^{49}$ Aliya'nın çocuklarından aldığı desteğe bakılarak şu ifadenin kullanılması doğru olabilir: Oluşan şartlar gereği hayatın zorluklarına karşı bazen çocuklar da, ebeveynlerine güç ve destek verebilirler.

Aliya tamamı kız olan torunlarına karşı çok ilgilidir ve onlar hakkında da kızlarındakine benzer bir sevgiden bahseder:

"Evliliğimden sonra ailenin kadın üyeleri tarafından daha önce hiç olmadığı kadar çevrelenmiştim. Eşim Halida'dan başka, kızlarım Leyla ve Sabina ve onların ardından da beş kız torunum geldi: Yakın aile çevremde o latif cinsin tam sekiz üyesi bulunuyordu. Kadınların yaşama tarzlarını ve karşılaştıkları sorunları anlamaya başladım. Erkek olduğum için Tanrı'ya şükran borçluydum ve kadınlara, yani insanlığın daha az şanslı olan kısmına karşı bir dayanışma borcum varmış gibi geliyordu." $" 50$

İlk torunu olan Selma'ya daha önce ve daha sonra hiç kimseye karşı hissetmediği özel bir sevgiyi anlatmak için kendisinin de komik bulduğu bir anısında, Libya'ya iki haftalık bir ziyaret için gitmek zorunda kalınca deniz kenarında ailesiyle tatilde olan Selma'yı görme amacıyla çok meşakkatli bir yolculuğa nasıl çıktığını heyecanla dile getirir. ${ }^{51}$

İnsanın yetiştirilmesinde kalıtsal olarak hangi aileden geldiği, geniş aile veya çekirdek ailenin insan üzerindeki etkisi bilimsel açıdan ve pratik olarak ispatlanmış bir durumdur. Evde alınacak her türlü olumlu veya olumsuz eğitim daha sonraki evrelerde alınacak eğitime temel oluşturur. ${ }^{52}$ Onun eserlerinde ve onu yakından tanıyanların anlattıklarında görülen ortak nokta; aile hayatının bütün kademelerinin ve tüm ilişkilerinin eğitim ve öğretime dair mesajlarla dolu olmasıdır. Bardhi'nin de tespit ettiği gibi farkll1ıklara rağmen birlikte yaşanabileceğini hedefleyen Aliya, manevî endişe taşıyan tüm insanların kendisinden istifade edebileceğini düşünerek ve birçok açıdan rol model olabileceğinin şuuruyla yaşar ve yaşadıklarını özenle kaleme alır. ${ }^{53} \mathrm{Bu}$ anlama gelebilecek olan benzer bir ifadeyi Gündüz'de kullanır: "Aliya bizleri inşa etti ve etmeye devam ediyor. Onun sayesinde İslam öykü olmaktan çıktı ve hayatın kendisinde bir karşılık bulmaya başlad.." 54 Aynı şekilde

\footnotetext{
${ }^{48}$ Yorulmaz, Bilge Lider Aliya İzzetbegoviç, 74-80; Detaylı bilgi için bkz. Aliya İzzetbegoviç, Özgürlüğe Kaçışım: Zindandan Notlar, Trc. Hasan Tuncay Başoğlu, 24. Bsk., (İstanbul: Klasik Yayınları, 2017), 335-394.

49 Demirci, "Aliya İzzetbegoviç’'in Hayatında ve Eserlerinde Aile ve Kadın”, 370.

50 İzzetbegoviç, Tarihe Tanıklı̆̆ım, 24; http://www.irsadgenclik.org/bilge-kral-aliya-izzetbegovic/ (Erișim: 05.05.2020).

51 İzzetbegoviç, Tarihe Tanıklı̆̆ım, 24.

52 Orhan Gürsu, "Değişen Dünyada Aile ve Psikolojik Problemler", Dicle Üniversitesi İlahiyat Fakültesi Dergisi, C.17, S.1, (2015), 103.

53 İsmail Bardhi, "Aliya İzzetbegoviç-Bir Dindar ve Din Eğitimcisi”, Uluslararası Aliya İzetbegoviç Sempozyumu (11-12 Ekim 2008), Ed. Ömer Hakan Özalp-Kenan Gültürk, (İstanbul: Etkin Ajans, 2010), 123.

${ }^{4}$ Süleyman Gündüz, "Sade ve Bilge İnsan Aliya İzzetbegoviç", Hece Aylık Edebiyat Dergisi, S.229, (2016), 666; http://www.sanalbasin.com/suleyman-gunduz-yazdi-bir-kitle-heykeltirasialija-izetbegovic-15880526/ (Erişim: 05.05.2020).
}

Turkish Academic Research Review - Türk Akademik Araştırmalar Dergisi 
Aliya'nın hangi ailede dünyaya geldiği ve çocukluğundan ölümüne kadar yaşadıkları konusunda elde edilecek bilgiler, iyi bir ailenin kurulması ve sağlıklı bir neslin yetiştirilmesi hususunda da yararlı olabilir.

\section{Aliya'ya Göre Batı'da Kadın ve Aile Anlayışı}

Aliya, kültür ve medeniyete dair analizinde kadın ve erkek arasındaki farklılıkları belirtirken; kültürde kadın kadındır, erkek erkektir dedikten sonra medeniyetin erkek ile kadın arasındaki farklılıkları ortadan kaldıracağını ifade eder. ${ }^{55}$ Başka bir incelemesinde ise modern dünyada ailevi ve toplumsal olarak yaşanan bozulmayı daha çok kadınlardan annelik rollerinin çalınmasına bağlar. Onlar kullanılan veya tapılan bir nesne olurken ellerinden en önemli özelliği olan şahsiyeti alınır. ${ }^{56}$ Huzursuzlukların temel sebebi kapitalizmin kadını bir meta haline getirmesi ve anneliği değersizleştirmesidir. Sözde uygar ülkelerde kadının konumunun değiştiği fakat iyileşmediği görülür. Bunun nedeni anlayış değişikliğinin ardından kadınların iş hayatında ve sosyal alandaki sorumluluklarının dengesiz bir şekilde artmış olmasıdır. ${ }^{57}$

"Uygarlık, kadını hayranlık veya kullanım objesi yapmış fakat takdir ve saygıya layık tek şey olan şahsiyeti ondan almıştır. Bu durumla her gün biraz daha fazla karşılaşıyoruz. Fakat bilhassa çeşitli "Miss"lerin seçimlerinde ve manken veya fotomodel gibi kadınlara mahsus mesleklerde bu keyfiyet apaçık ortaya çıkıyor. Burada kadın artık insan denilen şahsiyet değildir. Olsa olsa "güzel hayvan"dan biraz daha fazladır." 58

Oluşturulmak istenen ütopyalar, materyalist felsefe gereği aileyi üretimin bir mekanizması olarak görür ve kadın-erkek arasında olması gereken aşk gibi romantik duygusal bağların gereksizliğini ortaya koymaya çalışır. Teorik olarak başlayan bu süreç uygulama alanı bulur ve üretim vasıtası olan aile müşterek mülkiyete dönüştürülerek toplumun ekonomik birliği için feda edilmeye başlanır. Bu durum hem Batı'da hem de Çin'de Mao tarafından topluma dikte edilir. ${ }^{59}$ Kadına tanımlanmış olan bu fonksiyon Batı'da gerçekleşen Sanayi Devrimi sonrasında dünyanın her tarafina yayılan sanayileşme süreciyle yoğunlaşır. Hızla açılan fabrikalarda ihtiyaç duyulan ucuz işçilik, kadınların çalışma hayatına girmesiyle karşılanır. ${ }^{60}$ Bundan dolayı 19. yüzyılın sonlarından itibaren kadınların büyük bir çoğunluğu eşitlik süslemeleriyle bedensel özelliklerine bakılmaksızın maden ocaklarında, demir yolu inşaatlarında bir anlamda çalışmaya mahkûm edilir. ${ }^{61}$ "Bir zamanlar Roma ileri gelenlerinin müstakbel anneye duyulan saygının bir ifadesi olarak anne adaylarının yanından geçerlerken eğilmeleri ve kadına sosyal hayatta değer atfetmeleri söz konusu olurken, 20. asırda anne, çalışmayan kişiler ile eş değer

55 İzzetbegoviç, Özgürlüğe Kaçışım: Zindandan Notlar, 231.

56 Aliya İzzetbegoviç, İslam Deklarasyonu, Trc. Rahman Âdemi, 35. Bsk., (İstanbul: Fide Yayınları, 2017), 64; Demirci, “Aliya İzzetbegoviç'in Eserlerinde Aile ve Kadın”, 373-374.

57 İzzetbegoviç, Özgürlüğe Kaçışım: Zindandan Notlar, 144.

${ }^{58}$ Aliya İzzetbegoviç, Doğu Batı Arasında İslam, Trc. Salih Şaban, 17. Bsk., (İstanbul: Klasik Yayınları, 2017), 244-245; Aygün, “Aliya İzzetbegoviç'te Din ve Siyaset”, 67.

59 İzzetbegoviç, Doğu Batı Arasında İslam, 237-238.

60 Faruk Karaarslan, "Aliya İzzetbegoviç'in Düşüncesinde Kadın ve Aile”, Hece Aylık Edebiyat Dergisi, S.229, (2016), 385.

61 İzzetbegoviç, Özgürlüğe Kaçışım: Zindandan Notlar, 158-159; Demirci, “Aliya İzzetbegoviç'in Eserlerinde Aile ve Kadın", 375. https://suffagah.com/aliya-izzetbegovicinkadin-istihdamina-yonelik-5-beyani (Erişim: 01.05.2020).

Turkish Academic Research Review - Türk Akademik Araştırmalar Dergisi 
görülmeye başlanır" ve "vasıfsız kişi" olarak kabul edilir.62 Öyle ki modern dönemde her meslek dalının eğitimine yönelik kurumlar gelişirken, anneliğe yönelik okulların veya okullarda derslerin varlığı dahi söz konusu değildir. Şu hâlde rahatlıkla söylenilebilir ki içinde yaşadığımız dönemde annelik toplumsal olarak tanınmış değildir. Annelik evde yaşamaya mahkûmiyet ile eşdeğer kabul edilirken, iş hayatında sahip olacağı imkânlar, elde edeceği para, doktorluk, mühendislik, öğretmenlik, marketlerde kasiyerlik yapma gibi meslekler ve bunlarla elde edeceği özgürce yaşayabilme imkânı, daha doğru bir tercih haline getirilir. "Medeniyet analığı kölelik ilan ederek kadına ondan kurtulmayı vaat eder." ${ }^{63}$ Bilinçli bir şekilde kadının annelik özelliği unutturulmaya çalışılır. Batılı fikir ve siyaset adamlarının arasında ev hayatının monoton ve dışarıdaki sosyal yaşamın daha verimli olduğunu, fabrikada iş̧i olarak çalışmanın daha fazla mutluluk getirdiğini savunanlar vardır. Kadınlar üretime katkı sağlamayan vasıfsız bir işçiden daha değersiz görülür ve aşağılanır. Üretime katkı sağlaması için psikolojik bir ortam oluşturulur. ${ }^{64} \mathrm{Bu}$ psikolojik baskı; doğum yapmak, çocuk yetiştirmek, ailenin maddi ve manevi geleceği için çaba sarf etmek yoluyla evde oluşturulan ekonomik katkının değersizleştirilmesi ve kabul edilmemesiyle gerçekleşir. Gününün tamamını bunların organize edilmesi ve yönetilmesiyle geçiren kadın; vasıfsız, çalışmayan insan olarak değerlendirilir. $\mathrm{Bu}$ göz ardı ediliş, kadında ve hatta ailenin tamamında dışarıya çıkmayı ve çalışmayı tetikleyecek bir psikolojik zeminin oluşmasına sebep olur. ${ }^{65}$ Hâlbuki "kendi evindeki kadın anne olmakla beraber, bir eş, daha sonra bir şekilde sağlıkçı, aşçı, pediyatrist, diyetisyen, hijyenist, pedagog, ev bütçesinin ekonomisti, terzi, çiçekçi ve dekoratördür. Bazıları ona ev mühendisi de derler." "66 Yapılan bir araştırmaya göre, yaptığı bu işler karşılı̆̆ında kendisine ücret ödenmeyen kadının küresel ekonomiye katkısı yıllık 4 trilyon dolara ulaşır ve bu, toplam dünya üretiminin üçte birine denktir. ${ }^{67}$

Kadında mükemmel derecede bulunan annelik vasfi; hisleriyle davranmasını ve kendisinde bulunan şefkat ve merhametiyle muamele etmesini zorunlu hale getirir. Bu durum onun bazı zamanlar soğukkanlı davranmasını engellediği gibi, aşırı fiziksel gücün şart olduğu yerlerde çalışmasındaki performansın düşmesine de sebep olur. Buradan hareketle kadınlardan soğukkanlı bir hâkim ya da tanık olması beklenmemelidir. Erkekler kendi canından bir canlı türetme yetisine sahip olmadıkları için duygusallıktan uzak ve daha soğukkanlı davranabilirler. Mahkemelerde bir erkeğin kendi çocuğunu mahkûm etmesi bir kadının kendi evladına ceza vermesine göre daha kolaydır. ${ }^{68}$ Fakat bu durum kesinlikle erkeğe daha üstün bir konum atfetmez tam aksine onların hiçbir zaman sahip olamayacağı anneliği kabullenmesine zorlar. Yaşadığımız bu dönemde kadının çalışma hayatındaki yeri ile ev hayatındaki konumu arasında çatışmalar yoğunlaşarak, gitgide içinden çıkılmaz bir hale getirilir. Kadın-erkek eşitliği kisvesiyle ve feminal

${ }^{62}$ Karaarslan, “Aliya İzzetbegoviç'in Düşüncesinde Kadın ve Aile”, 385; İzzetbegoviç, İslami Yeniden Doğuşun Sorunlarl, 46.

63 İzzetbegoviç, Doğu Batı Arasında İslam, 245.

64 https://www.dunyabizim.com/polemik/aliya-kadina-nasil-bakiyordu-h379.html (Erişim: 01.05.2020).

${ }^{65}$ İzzetbegoviç, Özgürlüğe Kaçışım: Zindandan Notlar, 85.

66 İzzetbegoviç, İslami Yeniden Doğuşun Sorunları, 47; http://www.irsadgenclik.org/bilgekral-aliya-izzet-begovic/ (Erişim: 05.05.2020).

67 İzzetbegoviç, Özgürlüğe Kaçışım: Zindandan Notlar, 93; https://suffagah.com/aliyaizzetbegovicin-kadin-istihdamina-yonelik-5-beyani (Erişim: 01.05.2020).

${ }^{68}$ Karaarslan, “Aliya İzzetbegoviç’in Düşüncesinde Kadın ve Aile”, 385; İzzetbegoviç, İslami Yeniden Doğuşun Sorunları, 49.

Turkish Academic Research Review - Türk Akademik Araştırmalar Dergisi 
anlayışların baskısıyla kadınlar kapitalist ekonomik sistemde, duygusal ve fiziksel yapılarına uygun olmayan işlerde çalıştırılır. Feminist hareketin amaçlarından biri: "Anneliğin yüceltilmesine karşı savaş"tır. ${ }^{69}$ Aliya feminizmi şu cümlelerle eleştirir:

"Feminist hareketin argümanlarından biri, kadının günümüze dek kendisini anne olarak ifade ettiği, şimdi ise kendisini bir şahsiyet olarak ifade etme zamanının geldiği şeklindedir. Onların muhakemesine göre anne ve şahsiyet zıt terimlerdir. Birilerinin bunu, bana açıklamasını isterdim. Hep şahsiyette annelikten daha şahsi ve daha zengin bir şey olmadığını, anneliğin muhteşem bir şahsiyet olduğunu düşünmüşümdür. Feminist diyalektik karıştırmaktadır."70

Pozitivistler, toplumda kadınla erkek arasındaki rollerin tabi olmadığını, erkek çocukların silahla, kız çocukların bebekle oynamasının ebeveynleri tarafından öğretildiğini söyleyerek ve bunu yetiştirme tarzına indirgeyerek eşitlik iddialarını desteklemeye çalışırlar. ${ }^{71}$ Aliya'ya göre modern hayatın kadın üzerindeki olumsuz etkileri aile hayatını da içinden çıkılmaz hale getirir. Karı-koca arasındaki sorunların artması mutsuz ve doyumsuz gençlerin çoğalmasına da sebep olur. Özel de benzer bir açıklamayla çağdaş topluma göre aile tarifini yaparken ailenin kendi içinde bölündüğünü, dede-baba-torunun aynı ailenin mensubu olmaktan çıktığını ve çekirdek ailenin mensubu olan ana, baba, çocuğun kendilerine mahsus bağımsız alanlar talep ettiklerini dile getirir. ${ }^{72}$ Aliya açısından çekirdek ve küçük aile anlayışını tercih eden Batı ülkeleri doğum oranlarının azalmakta olduğunu görünce, teşviklerle bu durumun önüne geçmeye ve bu kurumun önemini anlatmaya çalışırlar. Gelişmiş denilen toplumlarda -içine düştükleri sarmaldan dolay1- nüfus piramidinde yaşlıların başı çektiği, ailenin çaresiz bir şekilde tek bir çocuğu tercih ettiği, kadınların bedeni deformelerden ve sosyal hayata uzak kalmaktan korktukları görülür. Annelik şefkatiyle kendini çocuk yetiştirmeye adamanın yerine genç ve güzel kalma, sosyal olma ve kendini işine adama tercih edilir. ${ }^{73}$ Yine günümüz dünyasında çalışan kadın; çocuklarını sevgi için değil para için çalışan eğitimsiz bakıcılara emanet etmek zorunda kalır. En iyi ihtimalle eğitimli ancak çocuğu herhangi bir eşyadan farklı görmeyebilecek anaokullarında veya kreşlerdeki memurlara bırakmakla karşı karşıyadır. Kreşlerdeki mürebbiyeler çocukların duygusal tarafını geliştiremezler, onları sadece korur ve onlara birtakım bilgiler öğretebilirler. ${ }^{74}$ "Anne insanı doğurur ve yetiştirir; çocuk bakım evleri ise toplum üyesini, ütopyanın müstakbel mensubunu eğitir. Çocuk bakımevi fabrikadır, eğitim makinesidir." 75 Bir başka açıdan anne ile aile dinî dünya anlayışına ait iken; bakıcılar ve kreşler kapitalist dünya görüşüne ait olgulardır. Amerikalı bir psikolog tarafından yapılan araştırmanın neticesinde; "Anne ve babalarının çok meşgul olmaları ve onlara ilgi göstermedikleri için hizmetçilere emanet ettiklerinden dolayı

${ }^{69}$ İzzetbegoviç, Özgürlüğe Kaçıșım: Zindandan Notlar, 143.

70 İzzetbegoviç, Özgürlüğe Kaçışım: Zindandan Notlar, 29; Demirci, “Aliya İzzetbegoviç’in Eserlerinde Aile ve Kadın", 376.

${ }^{71}$ Demirci, “Aliya İzzetbegoviç’in Eserlerinde Aile ve Kadın”, 374; İzzetbegoviç, Özgürlüğe Kaçışım: Zindandan Notlar, 99-100.

72 İsmet Özel, Üç Zor Mesele, 10. Bsk., (İstanbul: Tiyo Yayınları, 2019), 298.

73 Aygün, "Aliya İzzetbegoviç’te Din ve Siyaset", 69; İzzetbegoviç, Doğu Batı Arasında Islam, 243.

74 İzzetbegoviç, İslami Yeniden Doğuşun Sorunlarl, 49-50; http://www.irsadgenclik.org/bilgekral-aliya-izzet-begovic/ (Erişim: 05.05.2020).

75 İzzetbegoviç, Doğu Batı Arasında İslam, 242; Aygün, “Aliya İzzetbegoviç’te Din ve Siyaset”, 68.

Turkish Academic Research Review - Türk Akademik Araştırmalar Dergisi 
zengin aile çocukları, hapishanelerde doğan fakat annelerinin yanında büyüyen çocuklardan daha ileri olmadıkları sonucuna vardı." ${ }^{, 76}$

Aliya'ya göre uygarlık ve onun yansıması olan şehirleşme, konfor ve zenginlik mutluluk yerine mutsuzluğu arttırdığı gibi birçok açıdan bireysel ve toplumsal çöküntüye neden olur. ${ }^{77}$ Modern hayat tarzı, aile yapısının çözülmesiyle birlikte boşanmaların artmasına sebep olur. Avrupa'da evlilik ve çocuk doğurma sorumluluğundan kaçma eğilimi ile boşanmalar korkutucu boyutlardadır. ${ }^{78}$ Amerika Birleşik Devletleri'nde, Avrupa'nın genelinde ve Sovyetler Birliği'nde çalışan kadın sayısının artması meşru evliliklerin ve çocuk sayılarının düşmesine ${ }^{79}$ sebep olurken gayri meşru birlikteliklerin ve çocukların rakamlarını artırır. Aliya, Doğu Bloku ülkelerinde bu durumun daha fazla artmasının sebebini devlet tarafindan ideolojik olarak desteklenmesine bağlar. ${ }^{80}$ Sosyal hayat eşler arasında aldatmayı ve gizli poligamiyi normal hale getirir. ${ }^{81}$ Aliya bu düşüncesini istatistiksel verilerle açıklar; dinî değerlerin zayıflamasıyla birlikte 1920 senesinden itibaren İsviçre'de boşanma oranı dört katına çıkar. 1960 yılında Kaliforniya'da her iki evlilikten biri boşanma ile sonuçlanır. Aliya, 1960 yılında Amerika'da her 100 evlenmeye karşı 26 boşanmanın var olduğunu ve bu oranın 1975 yılında \%48'e yükseldiğini, Sovyetler Birliği'nde ise; 1960 senesinde boşanmaların oranı \%10 iken 1973 senesinde \%27'ye ulaştığını, Çek Cumhuriyeti'nde 1945-1975 yılları arasında boşanmaların üç katına çıktığının altını çizer. Fransa da ortaokul kız öğrencilerinin ileriye yönelik planlarını ölçmek için yapılan bir araştırmada, bağımsız olma ve rahat bir hayat yaşama arzusu ilk sırada yer alırken aile kurma isteğinin son sırada yer aldığ gözlemlenir. ${ }^{82}$ Orta yaşlarda fikri değişse de Batı'da bulunan genç bir kadının arzusu: "Anne olmak istiyorum ama hanım olmak istemiyorum." Bu anlayış bir anlamda onun parolasıdır. ${ }^{83}$ Aliya'ya göre ailenin gün geçtikçe daha yoğun bir şekilde çözüldüğü yer Batı'dır ve orada en kötü durumda olanlar da yaşlılardır. Çünkü ahlâkî ve dinî ölçüleri terk eden ve sadece akli gerekçeleri tanıyarak ateizmin ve deizmin büyümesine sebep olan modern dünya giderek daha yoğun bir tarzda gençliğin tercihlerine ve zevklerine uygun bir şekil almaya başlar. Anne-babayı, aileyi tanımayan anlayış, yaşlıları her zaman yalnızlığa mahkûm ederken aralarında nispeten şanslı olanları sığınma ve huzur evlerine gönderir. ${ }^{84}$ Aliya bu durumun bir ironi oluşturduğunu şu ifadeyle açıklar: "Çocuk bakım evlerinde anne-babasız çocuklar, huzur evlerinde ise çocuksuz anne-babalar." 85

Medeniyet ihtiyaçları çoğaltıp konforun vazgeçilmezliğini pompalarken insanın elinden küçüğe sevgiyi, büyüğe saygıyı ve evdeki sıcaklığı alır. Bunları

\footnotetext{
76 İzzetbegoviç, İslami Yeniden Doğuşun Sorunları, 51.

77 İzzetbegoviç, Doğu Batı Arasında İslam, 108-109.

78 İzzetbegoviç, Ö̈zgürlüğe Kaçışım: Zindandan Notlar, 100-101; Karaarslan, "Aliya İzzetbegoviç’in Düşüncesinde Kadın ve Aile”, 386; İzzetbegoviç, İslami Yeniden Doğuşun Sorunlarl, 56

79 İzzetbegoviç, Doğu Batı Arasında İslam, 240-244.

80 İzzetbegoviç, Doğu Batı Arasında İslam, 240.

${ }^{81}$ Demirci, "Aliya İzzetbegoviç'in Eserlerinde Aile ve Kadın", 373.

${ }^{82}$ Karaarslan, “Aliya İzzetbegoviç’in Düşüncesinde Kadın ve Aile”, 386; İzzetbegoviç, Doğu Batı Arasında İslam, 239; İzzetbegoviç, İslami Yeniden Doğuşun Sorunları, 54-55.

83 https://suffagah.com/aliya-izzetbegovicin-kadin-istihdamina-yonelik-5-beyani (Erişim: $01.05 .2020)$.

84 İzzetbegoviç, Doğu Batı Arasında İslam, 186; Karaarslan, "Aliya İzzetbegoviç'in Düşüncesinde Kadın ve Aile", 387.

85 İzzetbegoviç, Doğu Batı Arasında İslam, 245; Demirci, “Aliya İzzetbegoviç'in Eserlerinde Aile ve Kadın”, 374 .
}

Turkish Academic Research Review - Türk Akademik Araştırmalar Dergisi 
gerçekleştiren Batı, oluşabilecek siyasi veya sosyal tepkileri engellemek için "cinsel özgürlük" adı altında yeni bir aldatmaca içerisine girer ${ }^{86}$ Aliya, özellikle sektör açısından çekim maliyeti ucuz ancak etkisi büyük olan bu sapkınlığa dikkat çeker. "Bazılarına göre pornografi, toplumun özgürlük ve demokratikleşme biçimlerinden biridir. Pornografi, diğer şahsın, özellikle de kadının ahlâkî bütünlüğünü küçümsemektedir." ${ }^{87}$ Cinsel özgürlük, kadına dair hakları kendisine teslim etmediği gibi özgürlük alanını daraltır ve özel olan saygıya değer kişiliğini zedeleyecek durumların ortaya çıkmasına sebebiyet verir. Aliya'nın bu konuya dair aktardığı şu alıntı dikkat çekicidir: "Pornografi: teori, tecavüz: uygulama. Bunlar kadınların pornografi karşıtı bildirilerinin birinden alınan kelimeler" dir. ${ }^{88}$

"Bazı haberlere göre Batı Almanya'da yılda 50.000, ABD de yaklaşı 250.000 tecavüz vakası kaydediliyor. İlginç olanı, cinsî özgürlüğün bulunduğu ülkelerin aynı zamanda tecavüz sayısıyla ilgili listenin zirvesinde yer alan ülkeler olmaları. Bu suçların fiili sayısı muhtemelen çok daha büyük, çünkü tecavüze uğrayan kadınların birçoğu, özellikle muhafazakâr çevrelerden gelenler bu hadiseyi ihbar etmiyorlar." 89

Bütün bunlarla anlaşılan medeniyetin geçmişten, günümüze ve yoğunlaşarak geleceğe kadının ve ailenin teorik olarak bitmesiyle yetinmeyeceği, onu pratik hayat içerisinden tamamen çıkartmaya çalışacağıdır. "Aile içinden evvela erkek dışarı çıkmıştır; sonra kadın ve en son çocuklar." "90 Ortaya çıkan durum; hedeflenen yapı oluşuncaya kadar birbirinden koparılan aile bireylerinin tek tek yalnızlaştırılıp dışarıda avlanır hale getirilmek istenmesidir.

\section{Aliya'ya Göre İslam Dünyasında Kadın ve Aile Anlayışı}

Aliya, kendisini tanımlarken referans kaynağının ne olduğunu beyan babında: "İlk gençlik yıllarımdan itibaren faaliyetlerimin ilham kaynağının İslam düşüncesi olduğu bir gerçektir. Benim için gelecekte de böyle olacaktır"91 açıklamasını yapar. Bulunduğu yerin tarifini yaparken ise şu net ifadeleri kullanır: "Dinî açıdan Doğulu, eğitim bakımından Batılıyız. Kalben bir dünyaya, aklen diğerine ait bulunuyoruz"92, yine başka bir yerde; "Akıll ve düşünce olarak Batıll, ruh ve duygu olarak Doğulu birisiyim. İslam ve Müslümanlara hizmet ederken aynı zamanda tüm sağduyulu insanların hizmetinde bulunuyorum" ${ }^{\prime 93}$ değerlendirmelerinde bulunur. Yaptığı bu açıklamalardan onun özgüveni yüksek, aşağglık kompleksine sahip olmayan, hoşgörülü ve adil bir yaşam felsefesine sahip olduğu görülebilir. Aynı şekilde eserlerinde, konuşmalarında ve pratiğinde objektif bir bakış açısına da sahip olduğu, insana insan olduğu için değer verdiği rahatlıkla söylenebilir. Onun en önemli

${ }^{86}$ Demirci, “Aliya İzzetbegoviç'in Eserlerinde Aile ve Kadın”, 377.

87 İzzetbegoviç, Özgürlüğe Kaçışım: Zindandan Notlar, 133; Ayrıca bkz. Oya Çetintaş, "Aliya İzzetbegoviç'in Siyaset Felsefesi”, (Yayımlanmamış Yüksek Lisans Tezi, Uşak Üniversitesi Sosyal Bilimler Enstitüsü, Uşak: 2018), 33, 38.

88 İzzetbegoviç, Özgürlüğe Kaçıšım: Zindandan Notlar, 154.

89 İzzetbegoviç, Özgürlüğe Kaçışım: Zindandan Notlar, 148-149; Demirci, "Aliya İzzetbegoviç'in Eserlerinde Aile ve Kadın”, 377.

90 İzzetbegoviç, Doğu Batı Arasında İslam, 239.

91 İzzetbegoviç, Konuşmalar, 65.

$92 \mathrm{https} / /$ www.tyb.org.tr/20-yuzyilda-insanligin-onurunu-kurtaran-liderdir-aliya-18888yy.htm (Erișim: 17.05.2020); İzzetbegoviç, Konușmalar, 216.

93 İzzetbegoviç, Konuşmalar, 66; Bülent Koçoğlu, "Aliya İzzetbegoviç'in Eğitim, Din Eğitim ve Öğretimi Görüşleri”, (Yayımlanmamış Yüksek Lisans Tezi, Akdeniz Üniversitesi Sosyal Bilimler Enstitüsü, Antalya: 2019), 1.

Turkish Academic Research Review - Türk Akademik Araştırmalar Dergisi 
düsturu Allah’a ve kendimize karşı sorumluluğumuzdur dediği; “insan olmak ve insan kalmaktır." 94

Batı'da ciddi bir çöküş yaşanırken çağdaş İslam düşüncesinin önemli tartışma konularından birisi de Müslüman dünyada kadın ve ailenin konumudur. Çünkü Müslümanların toplumsal hayatı açısından son derecede önemli olan bu kurum, Batılılaşmanın her alanda başlattığı dönüşüme maruz kalır ve birtakım bozulmalar yaşamaya başlar. Bu değişimler büyük oranda dinî ve kültürel anlamda İslam ahlak anlayıșının yerine modern değerlerin ortaya koyduğu Batılılaşmış ahlak anlayışı ve toplumsal ilişkiler bağlamında ortaya çıkar. Teknolojik ilerleme, internet ve sosyal medya, şehirleşme, yeni mekânsal düzenlemeler, hızlılıkla birlikte sorumsuz yaşamın önem kazanması vb. sebepler bu değişimin baş aktörleridirler. İslam ve Müslümanlar hakkında Batı ve Batılılaşmış kimseler farklı konulara dair birçok eleştiri getirirler. Yapılan eleştiriler arasında Müslüman kadınla ve onun İslâm toplumundaki yeri ile alakalı konular önemli bir yekûn tutar. Bu konuyla ilgili ana başlıklar; Müslüman kadının sadece ev hayatıyla sınırlandırıldığı, ev dışında özelde veya kamuda çalışma imkanlarının olmadığı, yeteri kadar özgürleşemediğiyle birlikte çok eşlilik, cinsel hayat, eğitim hakkı gibi mevzulardır. Aliya, Batılı düşünürlerin Müslüman kadınlara dair benimsedikleri yanlış algılara yönelik savunmaya geçilmesinin gereksiz olduğunun tespitini yapar. ${ }^{95}$ Yine İslam dünyasında kadının yeri ve önemine dair mevcut bulunan düşünce ve pratik zeminine de eleştirel yaklaşır. Ancak onun rahatsızlığı Batı dünyasının eleştirel yaklaşımından tamamen farklıdır. Batılı düşünürler, Müslüman kadınların Avrupa ülkelerindeki hemcinsleri gibi olmadığından veya Müslüman toplumların moderniteye ayak uyduramadığından dolayı negatif bir tavır takınır. Aliya'nın farklı duruşu Müslüman toplumlarda coğrafyadan coğrafyaya değişmekle birlikte vahiy ve sünnet doğrultusunda elde edilen bilgi ile pratik hayatın ayrılığındaki yoğunluktan kaynaklanır. ${ }^{96}$ Daha açık bir ifade ile onun endişesinin sebebi, Müslüman toplumların ve bu toplumlarda yaşayan kadınların konumunun yeteri kadar İslamî olmayıșıdır. Batılıların veya içerde bulunan bazı aklı evvellerin değerlendirirken yaptığı, Müslümanın hayatında bulunan her şeyin İslamî ya da vahye dayandığı zannı büyük bir metodolojik hatayı içerir. "Çünkü Kur'an tek olmasına rağmen her Müslüman toplumda uygulamaları farklıdır. Örneğin bazı toplumlarında peçe hadisesi hiçbir şekilde bilinmez iken, bazı yerlerde bu uygulama bir dogma olarak kabul edilir.” Aliya, peçenin Hz. Peygamber döneminde kullanılmadığını, ilk defa Harun Reşid'in kız kardeşi Uleyya tarafından kullanılarak bir modaya dönüștüğünü ifade eder. ${ }^{97} \mathrm{Bu}$ uygulama daha sonraki dönemlerde bazı bölgelerde dinî bir kurala dönüşürken bazı coğrafyalarda ise özgürlüğün kısıtlandığı düşüncesinden hareketle uygulama dişında tutulur. Bu ve buna benzer örneklerden yola çıkarak Müslüman toplumlarda kadının özgürlüğünün tamamen kısıtlanmasının nedenini dinî faktörlerde aramak yersizdir. İslam, tektir ve kendi kaynaklarında yazılı olan şeydir. Ancak bir hayat uygulaması olarak onu pratiğe aktaracak bireyin ve toplumun özelliğine göre farklılık göstermesi normaldir. Kadın ve aile konusunda yaşanan

94 İzzetbegoviç, Konuşmalar, 75.

95İzzetbegoviç, $\quad$ Íslami $\quad$ Yeniden Doğuşun Sorunlarl, https://www.yenisafak.com/hayat/bosna-bilge-lider-aliyayi-ozlemle-aniyor-2550485 (Erișim: 17.05.2020).

96 Demirci, "Aliya İzzetbegoviç'in Eserlerinde Aile ve Kadın”, 372; İzzetbegoviç, İslami Yeniden Doğuşun Sorunları, 39; Aygün, "Aliya İzzetbegoviç’te Din ve Siyaset”, 65-70.

${ }_{97}$ İzzetbegoviç, İslami Yeniden Doğuşun Sorunları, 40-41; Karaarslan, "Aliya İzzetbegoviç’in Düşüncesinde Kadın ve Aile", 383.

Turkish Academic Research Review - Türk Akademik Araştırmalar Dergisi 
sorunların sebebi dinî kuralların sosyal hayata yön vermemesi, daha açık bir ifadeyle bütün Müslümanlar tarafından İslam'ın gündelik yaşama aktarılamamasıdır, denilebilir. Dinî kuralların hayata geçirilmesi demek bir diğer açıdan cinsel arzuların bastırılması veya yok edilmesi demek değildir. Kur'an-1 Kerim birçok yerinde kadın-erkek ilişkilerinde hijyene, temizliğe ve ölçülü olmaya davet ederken azgınlar gibi değil iffetli insanlar olarak davranılmasını emreder..$^{98}$ İslam meşru yakınlaşmayı evlilik ile gündelik hayatın içerisine alırken sağlıklı bir zemin oluşması adına aile ve nikah hukuku oluşturur. ${ }^{99}$ Amerikalı yerliler yani Kızılderililer evliliği daimî kabul edip boşanamazlarken, modern hayat ise evliliği değersizleştirip boşanmayı alabildiğine kolaylaştırır, İslam "bu ikisi arasında"dır. ${ }^{100}$ Boşanmayı pek hoş olmayan hela1 ${ }^{101}$ dairesi içerisine alarak sınırlandırılması yönünde ölçüler belirler ve oluşabilecek mağduriyetlerin azaltılması için kadına parasal imkân (nafaka) sunulması kaidesini koyar. ${ }^{102}$

"İslam arzuların yok edilmesini değil kontrol edilmesini ister. Seksin boğulmasını değil, seks disiplini talep eder. İslam'a göre doğanın olduğu yerde şeytan değil Allah ve O’nun eseri vardır. Bu sebeple İslam, sadece ibadet, fedakârlık, tövbe, zühd, iyilik, sevgi kavramlarıyla ifade edilmez. Beden, iktidar, mücadele, adalet, sağlık, ilim, ödül ve güç kavramlarının kullanılması da gerekir."103

Aliya, çok eşlilik (poligami) konusunu Batı'daki haliyle İslam'ın yaklaşımını kıyaslayarak açıklar. İslâm toplumunun gündelik hayatında çok küçük ve dönemsel öneme sahip iken Batılılar tarafından Müslümanlara yönelik olarak poligaminin kınanması ikiyüzlülüktür. Batı'da çiftler evlenirken birbirlerine verdikleri iffetli kalma sözünü çoğunlukla unuturlar ve gizli bir poligami hayatı sürerler. ${ }^{104}$ "İslam'ın tüm müesseseleri gibi evlilik de öyle bir çözümdür ki, manevî emellerle bedeni ihtiyaçlar arasında uyum sağlamayı amaçlamakta, sevgiyi reddetmeden iffeti muhafaza etmeyi sağlamakta"dır. ${ }^{105}$ Kur'an-1 Kerim'in çok eşliliğe izin vermesinin sebebini Aliya, zinanın kesin olarak yasaklanmasından sonra evlilik hayatının yalan üzerine devam etmesini istememesi ile yorumlar. Böyle olmasına rağmen çok eşlilik İslam toplumunda çok yaygın olarak görülmemekle birlikte çeşitli sınırlandırmalar

98 İzzetbegoviç, İslami Yeniden Doğuşun Sorunları, 41-42. Örneğin bkz. İffetin önemine dair Nur Suresi 31. ayette şöyle buyurulur: "Mümin kadınlara da söyle, gözlerini haramdan sakınsınlar ve iffetlerini korusunlar. Açıkta kalanlardan başka süslerini göstermesinler. Başörtülerini yakalarının üzerinden bağlasınlar. Kocaları, babaları, kocalarının babaları, kendi oğulları, kocalarının oğulları, erkek kardeşleri, erkek kardeşlerinin oğulları, kız kardeşlerinin oğulları, kadınları, hizmetlerinde bulunan köleleri ve câriyeleri, cinsel arzusu bulunmayan erkek hizmetçiler, kadınların cinselliklerinin farkında olmayan çocuklar dışında kimseye süslerini göstermesinler. Yürürken, gizledikleri süsleri bilinsin diye ayaklarını yere vurmasınlar. Ey müminler! Hepiniz Allah'a tövbe edin, umulur ki kurtuluşa erersiniz!" https://kuran.diyanet.gov.tr/tefsir/N\%C3\%BBr-suresi/2822/31-ayet-tefsiri (Erişim:07.06.2020).

99 Öztürk, "Nurettin Topçu ve Aliya İzzetbegoviç’te Din Anlayışı”, 64-65.

100 İzzetbegoviç, Özgürlüğe Kaçışım: Zindandan Notlar, 185-186.

101 Detaylı bilgi için bkz. "Helâl şeyler içerisinde Allah'a en sevimsiz geleni boşamadır." (Ebû Dâvûd, "Ṭalâḳ", 3) ve "Evlen, fakat boşanma, Allah zevk için evlenip boşanan erkek ve kadınları sevmez." (Heysemî, Mecma 'u'z-zevâ' id, IV, 335) gibi hadislerde boşanmanın dinen hoş karşılanmadığı açıkça belirtilmiştir. https://islamansiklopedisi.org.tr/talak (Erişim: 07.06.2020).

102 İzzetbegoviç, İslam Deklarasyonu, 64-65; Melike Dalkılıç, "Bir Çağdaş İslam Düşünürü Olarak Aliya İzzetbegoviç", (Yayımlanmamış Yüksek Lisans Tezi, Necmettin Erbakan Üniversitesi Sosyal Bilimler Enstitüsü, Konya: 2019), 81.

103 İzzetbegoviç, İslami Yeniden Doğuşun Sorunları, 42-43.

104 Demirci, “Aliya İzzetbegoviç'in Eserlerinde Aile ve Kadın”, 373.

105 İzzetbegoviç, Doğu Batı Arasinda İslam, 334.

Turkish Academic Research Review - Türk Akademik Araştırmalar Dergisi 
getirilerek bazı özel şartlara bağlanır. Onda oluşan genel kanaat çok eşlilik tamamen kaldırılmalıdır ${ }^{106}$ ve eğitimli kadınların bu konuya dair az da olsa, mevcut bulunan sorunları tamamen çözme konusunda, rol alabilecekleri yönündedir. ${ }^{107}$

Aliya'nın kadın ve aileye dair üzerinde durduğu temel meselelerden biri de “İslam'da kadın-erkek eşitliğinin olup olmadığıdır. Ona göre İslam'da kadın-erkek eşitliği hem vardır hem yoktur." İnsan ve şahıs olarak; kişilik hakları, ahlâkî ve insanî sorumlulukların taşıyıcısı olması bakımından eşitlik mevcut iken, “Avrupa'da genel olarak anlaşılan aile ve toplum içinde görevlerin birebir aynılaştırılması anlamında" eşitlik İslam'da söz konusu değildir. ${ }^{108} \mathrm{O}$, kavramların sorumsuzca kullanılmasına karşı çıkarak eşitlik ve özdeşlik kavramlarının farklılığına dikkat çeker. "İnsanlar eşittir ama özdeş değildir. Bu bağlamda eşitlik ve özdeşlik iki farklı kategoridir. Allah'ın huzurunda eşitiz, tabiat bakımından özdeşiz... Ruhlar (fertler)

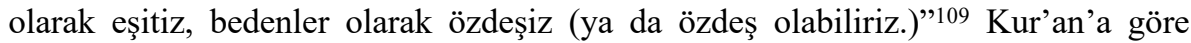
kadın ve erkeğin İslam karşısındaki konumu aynıdır. Müslümanlık, "ahlâkî ve dinî sorumluluklar noktasında kadın ve erkeğe aynı mesuliyetleri yükler." Bu bağlamda sorumluluğun benzer olması, değerler dünyasında her iki insan arasındaki farkı kaldırır ve eşit noktaya getirir. ${ }^{110}$ Fakat bu iki ayrı cinsin yaratılışlarından gelen bir takım değişik özellikleri vardır. Bu özellikler, ne erkeği kadın karşısında üstün kılar ne de kadını erkeğin karşısında küçültür. Bu tartışma vücut açısından "kalp mi daha önemli akciğer mi daha önemlidir?" tartışması kadar abestir."111 Zihin, duygu ve bedene yansıyan bu farklılıklar zaman zaman her iki cinsin sosyal hayat içerisinde farklı roller ve işlevler üstlenmesine neden olur. "İnsanların ruhî tarafını tanımazsanız, insanların eşitliğinin dayandığı yegâne esası kaybedersiniz. $\mathrm{O}$ zaman eşitlik dayanıksız boş bir laf olarak kalır." 112

Aliya, kadının ev dışında çalışmaktan men edilmesine karşı çıkar ve kazandığı ya da miras aldığı malı veya mülkü kendi tasarrufunda, dilediği gibi harcamaya hakkının olduğunu belirtir. ${ }^{113}$ İslam özel veya tüzel fark etmeksizin kadının çalışma hayatından tamamen dışlanmasını emretmez. Müslümanların tarihine bakıldığı zaman kadınların birçok alanda görev aldıkları bir gerçektir. Burada önemli olan, şartların kadının çalışmasını zorunlu hale getirmesi durumunda kişiliğini incitmeyen ve yeteneklerine uygun olan işlerde çalışabilmesidir. ${ }^{114}$ Aliya, ünlü tarihçi Hitti'den ${ }^{115}$ şu alıntıyı yaparak Müslümanların tarihinde kadınların sosyal hayat içerisinde üstlendikleri rolleri örneklendirir:

106 İzzetbegoviç, İslam Deklarasyonu, 64-65; Demirci, “Aliya İzzetbegoviç’in Eserlerinde Aile ve Kadın”, 373.

107 İzzetbegoviç, İslami Yeniden Doğuşun Sorunları, 57-58.

108 Karaarslan, "Aliya İzzetbegoviç'in Düșüncesinde Kadın ve Aile”, 384; Demirci, "Aliya İzzetbegoviç’in Eserlerinde Aile ve Kadın”, 384; İzzetbegoviç, İslami Yeniden Doğuşun Sorunlarl, 44.

${ }_{109}$ Demirci, “Aliya İzzetbegoviç’in Eserlerinde Aile ve Kadın”, 375; İzzetbegoviç, Özgürlüğe Kaçıșım: Zindandan Notlar, 208.

110 Karaarslan, “Aliya İzzetbegoviç'in Düşüncesinde Kadın ve Aile”, 384.

111 İzzetbegoviç, İslami Yeniden Doğuşun Sorunlart, 44; Demirci, “Aliya İzzetbegoviç'in Eserlerinde Aile ve Kadın", 372.

112 İzzetbegoviç, Doğu Batı Arasında İslam, 78.

113 İzzetbegoviç, İslami Yeniden Doğuşun Sorunları, 53; Karaarslan, "Aliya İzzetbegoviç'in Düşüncesinde Kadın ve Aile”, 385.

114 Demirci, “Aliya İzzetbegoviç'in Hayatında ve Eserlerinde Aile ve Kadın”, 373.

115 Philip Khuri Hitti ile ilgili detaylı bilgi için bk. https://islamansiklopedisi.org.tr/hittiphilip-khuri (Erişim: 07.06.2020).

Turkish Academic Research Review - Türk Akademik Araştırmalar Dergisi 
"Erken Abbasi hâkimiyeti esnasında kadın Emevî kız kardeşinin sahip olduğu özgürlüklerin aynısına sahipti... Sadece, erken dönemde yüksek ortamlarda bulunan, önde gelmiş ve devlet işlerinde önemli ölçüde etkili olmuş kadınlar değil, edebiyatta erkeklerle yarış içinde olan, şiir yazan, savaşa katılan ve komutanlık yapan Arap kızlar hakkında görüyoruz...v.s." 116

İslam, kadına kendi yaratılışına ve karakterine uygun toplumsal görevler verdiği gibi aldığı görevleri layıkıyla yerine getireceğine dair de ona güvenir. Bunun örnekleri tarih boyunca olduğu gibi günümüzde de mevcudiyetini ve önemini korur. Birçok alanda kadınlar ya ön planda ya da erkeklerle birlikte hayatın içerisinde değişik roller üstlenirler. Aliya İzzetbegoviç bu durumu verdiği örneklerle açıklar: 1965'te Pakistan'da Devlet Başkanlığı seçimlerinde Fatima Cinnah adaylığını koyarken Cezayir'de Avrupa'nın siyasi ve manevî tasallutuna karşı durmak için kadınlar birçok önemli roller icra ederler. ${ }^{117}$ Kadisiye savaşındaki yaralılarla destek için geri planda bulunan kadınlar ilgilenir. ${ }^{118}$ İslam kadına, "insan şerefi, yüksek derecede bağımsızlık ve bazı konularda tam eşitlik" tanır dedikten sonra; Yermük savaşında kadınların İslam ordusuna verdikleri desteği ve Fas'ta bulunan dünyanın en eski üniversitesi olan Kayravan Üniversitesinin iki Müslüman kadının vakfı olduğu bilgisini verir. ${ }^{119}$ Demokratik Eylem Partisinin çalışmalarına katılmaları için çok sayıda yetenekli kadının varlığına işaretle onlara kapıların açılmasını teklif eder. ${ }^{120}$ Bazı şartlar kadının istihdamını kaçınılmaz veya gerekçeli olarak karşımıza çıkartır. Örneğin kadın eşinin olmaması halinde çocuklarına veya anne babasına bakmakla karşı karşıya kalabilir. Bir diğer örnek; farzı misal kadının çocukları yoktur veya onları büyütmüştür dolayısıyla zamanını ev dışında faydalı olabileceği sivil toplum kuruluşlarında görev alarak değerlendirebileceği gibi farklı sektörlerde de çalışabilir. Şunu da unutmamak gerekir ki, o bizatihi anne olarak kendi başına zaten yeri doldurulamaz bir değere sahiptir.

Batı'da veya İslâm dünyasında kadınlara dair bir sorun varsa, bu meselenin çözümü onun anneliğindedir. Müslümanların arasında yaşanan toplumsal sorunların çözümü annelikte gizlidir. ${ }^{121} \mathrm{O}$ verimliliğin, doğumun, nesillerin sonsuz değişiminin adı ve doğrudan aktörüdür. Günümüz dünyasında annelik toplumsal olarak tanınmıș değildir, çalışmayan kişi olarak tanımlanır ve markette kasiyerlik veya kamuda iş̧̧ilik yapan kadın sosyal hakkı gereği emekli olabilirken; "sadece anne" olan kadın tüm bu haklardan mahrumdur. Annelik vasfinı değersizleştirip onu daha saygı görebileceği alana çekmeye çalışmak veya ona yeni ve süslü haklar vereceğini teklif etmek onun önemini artırmaz. Çünkü onda bulunan annelik hakkı insanlık tarihinin bildiği en evrensel ve en eski bir haktır. ${ }^{122}$ Yaratılışı itibari ile kadın erkekten apayrı bir varlıktır. Fizyolojik özellikleri, zekâsı, şefkat ve merhamete dair taşıdı̆̆ hisler, annelik duygusu gibi vasıflar avantaj veya dezavantaj olarak tanımlanmamalıdır. Aliya, onların çalışma hayatında veya sosyal hayat içerisinde olmaları gerektiğini savunur. Bu konuda önemli olan şey kadınlar için uygun koşulların oluşturulması ve çalışma saatlerinin diğer rollerini kısıtlamadan ayarlanması meselesidir. Uygun

\footnotetext{
116 İzzetbegoviç, İslami Yeniden Doğuşun Sorunları, 41.

117 İzzetbegoviç, İslami Yeniden Doğuşun Sorunlarl, 40.

118 İzzetbegoviç, Özgürlüğe Kaçışım: Zindandan Notlar, 326.

119 İzzetbegoviç, İslami Yeniden Doğuşun Sorunları, 31.

120 İzzetbegoviç, Konuşmalar, 119; Demirci, "Aliya İzzetbegoviç'in Eserlerinde Aile ve Kadın”, 379.

121 Karaarslan, "Aliya İzzetbegoviç'in Düşüncesinde Kadın ve Aile”, 384.

122 İzzetbegoviç, İslami Yeniden Doğuşun Sorunları, 48.
} 
koşula örnek olarak çocuk emzirme saatleri ve doğum izinlerinin süresi verilebilir. ${ }^{123}$ Özel sektörde ve kamuda çalışan annelerin doğum izinleri üç yıl olmalıdır. Çünkü çocuğun ilk üç yıl annesinden ayrılmaması hususunda hekimler ve sosyologlar ortak bir kanaate sahiptir. ${ }^{124}$ Yine Demokratik Eylem Partisi tüzüğünde çalışan eş ve anneler için kolaylaştırıcı tedbirler yer alır. Tüzükte aile şartlarına, çocuk sayısına göre bir hafta içerisinde daha az çalışma günü ve bir günde daha az çalışma saati değişikliği yapılabileceğini açıklar. Kadının aynı zamanda bir anne olduğu veya olabileceği asla unutulmamalıdır. Aliya'ya göre aile müessesesinin manevî ve ahlakî değerinin korunması sosyal ahengin muhafazası açısından son derece önemlidir. ${ }^{125}$ Aliya bu konu üzerinde oldukça fazla durur. Yaptı̆ğ ilk ve en belirgin değerlendirme geçmişi ve yaşadığı dönemi anlamamıza sebep olduğu gibi geleceğe dair de projeksiyonu olan bir değerlendirmedir. Ona göre aile ve toplum birbirinden tamamen bağımsız fenomenler değildir. Bilakis bu müessese toplumun ilk hali, çekirdeği olması bakımından hücresi olmamakla birlikte, süreci ve sonucu belirleyen nüvesidir. Aliya, ailenin 1977 Sovyetler Birliği'nin anayasasında "çalışan kolektif" olarak tanımlanmış olmasına karşı çıar. ${ }^{126}$ Çünkü toplumun geliştirilmesine dönük atılan her adım o güçlü yapıyı bozar; ailede duygu, hissiyat, samimiyet ve menfaatsiz temel üzere başlanan süreç, daha çok çıkar üzerine kurgulanmış topluma teslim edilerek sonuçlandırılır. Bu nedenle toplum, aile kurumunu hiçe sayarak yaşam ilkelerini ve şartlarını belirlememelidir. Aksine ailenin merkezde olan fonksiyonunu icra etmesine müsaade etmeli ve kültürel ancak saygın yapısına dokunmamalıdır. Günümüz İslam dünyasında ailenin konumunu konuşmaya başladığımızda dikkate almamız gereken en temel gerçek, Müslüman kadının sosyal hayattaki yeri ve önemidir. Aileyi aile yapan ve Anadolu'nun "aileyi dişi kuş yapar" meşhur ifadesiyle kendisine yer bulan kadının ailedeki konumu hayati derecede mühimdir. Kadının sosyal hayattaki konumuna dair en temelde üç yaklaşımdan bahsetmek mümkündür. Bunlardan ilki, modernist yaklaşımdır. Bu yaklaşım özellikle sanayi devrimiyle birlikte kadının dışarıda çalışmaya yönlendirilmesi ve iş gücü olarak sosyal hayatta rol almasıyla birlikte ailedeki konumunun zayıflatılması üzerine bina edilir. Bunun yanında hızla değişen dünyanın dayattığı bazı şartlar kadının iş hayatında rol alması gerektiğini bir zaruret olarak ortaya koyar. "Eğitim seviyesinin yükselmesi, diploma kültürünün yaygınlaşması", şehirleşmenin artması, bireyselleşmenin yaygınlaşması, çekirdek aile kavramının tercih edilmesi, kapitalist ekonomiyle birlikte ihtiyaçların artması, geçim sorunu yaşanması gibi koşullar onu farklı sektörlerde çalışmaya mecbur hale getirir. İkincisi, geleneksel yaklaşımdır. $\mathrm{Bu}$, bir diğer adıyla esasında ataerkil anlayışı zorunlu hale getiren sosyal düzenin adıdır. Gelenekçi anlayış daha çok her coğrafyanın kendi içinde yaşadığı kültürel durumla bağlantılıdır. Bu yaklaşım, kadının sosyal hayattaki konumunu tamamen sınırlandırır ve onu bir anlamda eve kapatır. Buna göre o sadece eşi ve çocukları için var olmalı, dışarda olup bitenle ilgilenmemeli veya sosyal anlamda bir görev yüklenmemelidir. Üçüncü yaklaşıma gelince, onu İslami bir yaklaşım olarak tanımlamak mümkündür. Vahiyden, Hz. Peygamberin hadislerinden ve İslam tarihindeki güzel örneklerden yola çıkarak oluşan bu anlayış modern yaklaşımı ve ataerkil yapıyı kabul etmemesiyle hatta onu değiştirmeyi amaçlamasıyla bilinir. ${ }^{127}$

123 İzzetbegoviç, İslami Yeniden Doğuşun Sorunları, 51.

124 Demirci, "Aliya İzzetbegoviç'in Eserlerinde Aile ve Kadın”, 372-373; İzzetbegoviç, İslami Yeniden Doğuşun Sorunlarl, 50-51.

125 İzzetbegoviç, Tarihe Tanıklı̆̆ım, 81

126 İzzetbegoviç, Doğu Batı Arasında İslam, 236.

127 Karaarslan, "Aliya İzzetbegoviç’in Düşüncesinde Kadın ve Aile”, 382; Çetintaş, "Aliya İzzetbegoviç'in Siyaset Felsefesi”, 42-46.

Turkish Academic Research Review - Türk Akademik Araştırmalar Dergisi 
Günümüzde kadının veya ailenin sosyal hayattaki konumuna dair İslam dünyasının tamamını kapsayan bir yaklaşımın yer edinmemiş olduğunu ve bu üç anlayışın da iç içe geçmiş bir hâlde yaşandığını kabul etmek gerekir. Aliya, üçüncü yaklaşımı tercih ederken hararetle bunu hem Batı'ya hem de Müslümanlara tavsiye eder. Onun düşünce dünyasının merkezinde insan vardır ${ }^{128}$ ve ona göre toplumsal dönüşüme bireyden başlanılmalıdır. Kalıcı bir bireysel ve toplumsal dönüşüm ancak insan yetiştirmekle sağlanabilir. Bunu başarabilecek olan kurumun adı ailedir ve ailede de bu fonksiyonu icra edecek olan kadındır. Çünkü bu müessese terbiyenin en temel yapı taşı olduğu gibi samimiyetin ve karşılıksız eğitimin yapıldığı yuvanın da adıdır.

\section{Eğitimli Bir kadının İyi Bir Birey ve Toplumun Oluşumundaki Rolü}

Aliya'nın her konuda olduğu gibi eğitim açısından kadına dair düşüncelerini de hayatının bütününde görmek mümkündür. Hayatında bulunan (annesi, eşi, kızları gibi) kadınlara yaklaşımına bakıldığında bunun sıradan bir yaklaşım olmadığı, bir değerler sistemi içerisinde şekillendiği görülebilir. Elbette bu değerler sisteminin adı İslam'dır. Dünyaya geldiği andan itibaren duygusal olarak annesine olan bağl1lığını; anne-çocuk ilişkisi ve duygusal bağı çerçevesinde anlamak mümkünken sonraki kısmı tamamen İslamî bakış açısıyla değerlendirmek daha doğru olur. Karakterinin oluşumunda etkili olan ailesinden aldığı terbiyeyi kendi çocuk ve torunlarının eğitiminde kullanır. ${ }^{129}$ Aliya'nın şahsiyetinin oluşumunda ve dünyaya bakışının şekillenmesinde içinde doğup büyüdüğü ailesinin büyük bir etkisi ve katkısı olur. Çocukluk, insanoğlunun yeşerdiği tohumdur derken bu dönemi insan hayatının en önemli evresi olarak değerlendirir ve nereye giderse gitsin, ne olursa olsun bu döneme dair izleri taşır. ${ }^{130}$ Özellikle şuur altına yerleşen ve onu uzun zaman kötü düşünce ve eylemlere karşı koruyacak ve bu konuda bir kalkan görevi görecek olan Müslümanlığın adet, gelenek ve göreneğe yani kısaca kültüre dönüşmüş ilk bilgilerini ailesinden alır. $\mathrm{O}$, bu durumu daha 15 yaşındayken okumakta olduğu lisede; komünizmin ideolojik, ateizmin "inançsızlık" olarak propagandasının yapıldığ bir yerde etkilendiğini ve kişisel tereddütlere düştüğünü ifade eder. Atalarından devraldığı dinin onu bir yere kadar koruduğunu sonrasında ise yoğun eleştirel okumaları sonrasında artık yeni baştan edindiği bir dine yani bir anlamda taklidi imandan tahkiki imana yükselerek sahip olduğunu böylelikle tereddütlerinden kurtulduğunu ve onu bir daha hiç bırakmadığını kısa otobiyografisinde açıklar. ${ }^{131}$

Toplumun temel taşı aile olduğu gibi bu kurumun da temel direği ve mürebbisi annedir. Geçmişten günümüze hatta geleceğe, değişmemiş ve değişmeyecek olan bu durum insanlığın meşru zeminde çoğalmasını sağladığı gibi düzgün bir şekilde eğitilmesini de gerçekleştiren ilk ve en doğru zemindir. ${ }^{132} \mathrm{Bu}$ direğin sarsılması, annelerden bu rolün gasp edilmesi aslında insanlı̆̆ın kendi felaketi olacaktır. Aliya bu duruma şu ifadeyle açıklık getirir:

"Bütün dinler, aileyi; insanın yuvası, anneyi de ilk ve yerine kimsenin geçemeyeceği bir mürebbi olarak telakki edip yüceltmeğe devam edeceklerdir. Öbür tarafta bütün ütopyalar sosyal eğitim, gündüz bakım evleri, kreşler ve çocuk bahçelerinden

\footnotetext{
${ }^{128}$ Akın, Karaarslan, Aliya İzzetbegoviç: Özgürlük Mücadelesi ve İslâm Düşünürü,42-43.

${ }^{129}$ Karaarslan, "Entelektüel Üzerine Bir Çalıșma: Aliya İzzetbegoviç Örneği”, 45.

130 İzzetbegoviç, Konuşmalar, 207.

131 İzzetbegoviç, Tarihe Tanıklığım, 13-16.

132 Aygün, “Aliya İzzetbegoviç’te Din ve Siyaset”, 66.
}

Turkish Academic Research Review - Türk Akademik Araştırmalar Dergisi 
heyecanla söz edeceklerdir. Bütün bu müesseselerin, adları ne olursa olsun, müşterek bir tarafı vardır: Annenin yokluğu ve çocukların ücretlilere terkedilmesi." ${ }^{133}$

Aliya'nın eğitim konusundaki ana ekseni "Yeryüzünün öğretmeni olabilmek için gökyüzünün öğrencisi olmak lazım"134 yaklaşımında olduğu gibi İslam kültürünün özelliklerini taşır. $\mathrm{O}$, ahlak merkezli bir eğitimi terbiye konusu yapar. Terbiye ve eğitim kavramları gerek kökleri itibariyle gerekse sonuçları itibariyle ayrı iki kavram olarak görülebilir. Ancak bu başlık altında rahatlıkla eğitim ve terbiye kavramını birlikte ve aynı anlamda kullanmak mümkündür. $O$, eğitime dair düşüncesini kendi içinde cevabı olan "Eğitimin amacı ne? Tam olarak gelişmiş bir insan şahsiyeti mi yoksa son derece profesyonel ve ihtisaslaşmış bir sanayi iş̧isi hayvan mı?" gibi sorularla açıklarken İslam'ın ve Batı'nın yaklaşım farkını da beyan etmiş olur. ${ }^{135}$ Bu gelişmiş şahsiyeti yetiştirmek için verilecek eğitimi ilk önce ailenin temeli olarak kabul edilebilecek olan kadınlar yürütür. Onların çocuk üzerindeki etkisi zorla öğreterek bilgi birikimini artırmak veya çeşitlendirmekten ziyade kişilik yapısını ve davranışa dönük istendik alışkanlıkları oluşturmada söz konusu olur. Bu bağlamda terbiye etme ve geleceğe ahlaklı bir birey yetiştirme açısından aile, merkezi ve odak bir noktaya haizdir. "Terbiye sadece bir güzel ahlak meselesi değildir, aynı zamanda bir zevk-i selim meselesidir"136 ve bu eğitimi verecek olan da evde annedir. ${ }^{137}$

Aliya İzzetbegoviç'e göre; “Herkes iyilik yapamaz, fakat herkes iyilik isteyebilir ve onu sevebilir. Birçok kişi haksızlıkların düzeltilmesine katkıda bulunamaz; fakat her insan kendine veya başkasına yapılan haksızlıktan nefret edebilir." 138 Haksızlıklara karşı olmak davranış eğitimi anlamında şuur altına yerleşen ahlaki bir bilinçtir ve bu öğretilmez ancak aile tarafindan çocuğun damarlarına zerk edilir. Bu bireyin geleceğini şekillendirecek önemli bir ilkedir. Türkiye'de Eğitim Bilimleri alanında kabul edilen tanımlardan Ertürk'ün tarifine göre eğitim; "bireyin davranışlarında kendi yaşantısı yoluyla ve kasıtlı olarak istendik değişme meydana getirme sürecidir." ${ }^{139} \mathrm{Bu}$ bilimsel tanımdan hareketle eğitimi kısaca formal veya informal ortamlarda kasıtlı bir şekilde bireye değerlerin kazandırılması ve kişiliğin oluşturulması süreci olarak tarif edilebilir. Yine aile için, çocuğa ahlaki ve insanlık değerlerini öğreten ilk ve en önemli yapıdır denilebilir. Aile fertlerinin kimisi bu süreçte olumlu yönde bilinçli rol oynarken kimisi de kendi doğallığı içerisinde pratik hayat dâhilinde farkında olmadan olumsuz yönde etki eder. ${ }^{140}$

Bu bağlamda Aliya'nın köken itibariyle nasıl bir aileden geldiğini öğrenmeye başlamak, verasetten almış olduğu özellikleri nasıl elde ettiğini anlamaya da sebep olur. Düşüncelerini ifade ederken merkeze hep İslam'ı ve İslami bakış açısını koyar. Kendi kişiliğinin oluşumuna sebep olan temel etkenin Müslümanlık olduğunu şu

133 İzzetbegoviç, Doğu Batı Arasında İslam, 241.

${ }^{134}$ Gündüz, "Sade ve Bilge İnsan Aliya İzzetbegoviç", 666; http://www.sanalbasin.com/suleyman-gunduz-yazdi-bir-kitle-heykeltirasi-alija-izetbegovic15880526/ (Erişim: 05.05.2020). https://fethigungor.net/dirilis-postasi/aliyayi-fikriyatinidavasini-anlamak/ (Erișim: 09.05.2020).

135 İzzetbegoviç, Özgürlüğe Kaçışım: Zindandan Notlar, 240.

136 İzzetbegoviç, Özgürlüğe Kaçışım: Zindandan Notlar, 30.

137 Gürsu, "Değişen Dünyada Aile ve Psikolojik Problemler", 102-103.

138 İzzetbegoviç, Doğu Batı Arasında İslam, 165.

139 Yıldız Kızılabdullah, "Kavramsal Çerçeve: Eğitim, Öğretim ve Din”, Din Eğitimi El Kitabı, Ed. Recai Doğan, Remziye Ege, (Ankara: Grafiker Yayınları, 2015), 42.

140 İzzetbegoviç, İslam Deklarasyonu, 58.

Turkish Academic Research Review - Türk Akademik Araştırmalar Dergisi 
ifadesinden anlamak mümkündür: "Benim ailemden aldığım İslami terbiye kişiliğimin oluşmasın da önemli etkiye sahiptir". ${ }^{141}$ Evdeki büyüklerin çocuklarını yetiştirirken almaları gereken sorumluluklar vardır. $\mathrm{Bu}$ sorumluluklardan birisi kendisinden sonra gelecek olan nesle söz ve davranışlarından kaynaklı utanmalarını gerektirecek bir hayat sürmemeleridir. Aliya'nın ailesi bu bakış açısıyla incelenecek olunursa görülecek olan şey; Müslüman bir aile olarak İslam'dan aldıkları doğruları çocuklarına aktardıkları ve insanî olarak çevrelerine olumlu bir iz bırakarak kendilerinden sonra gelecek nesle gurur duyacakları itibarlı bir aile geçmişi bırakmalarıdır. İslam dünyasında coğrafyalar farklı olsa da aile, sadece akrabalık bağıyla kurulan ilişkilerin kurumsal yapısının adı değildir. Bu kurum, aynı zamanda birey açısından şahsiyetin kazanıldığı, terbiyenin ve dinî eğitimin verildiği en önemli müesseselerden biridir. Medeniyet ve kültür bakımından İslam'ın dünya görüşünün ilk tatbik edildiği bir yuva, eğitim açısından bir okul ve ahlaklı bir sosyalleşmenin gerçekleşmesi açısından önemli bir yapıdır. Aliya'ya göre; her insanın doğumundan itibaren ilk eğiticileri annelerdir. Dolayısıyla erkekler gibi kadın olarak annelere de saygı duyulmalı ve çok iyi eğitim almaları sağlanmalıdır. Bir erkek bakış açısıyla kadınlar hakkında değerlendirme yapıldığında görülecek olan durum; onların bizim annelerimiz, kardeşlerimiz ve çocuklarımızı büyüten eşlerimiz oldukları gerçeğidir. Genel olarak içinde yaşadığımız dünyanın, özelde ise İslam dünyasının durumu mükemmel değildir. Daha iyi bir dünyada yaşamanın sırrı bugünkünden daha iyi bir gençlik yetiştirmenin içinde gizlidir. Bu gençliğin yetiştirilmesinde bastırılmamış, eğitim görmüş, yeniden onurları kazandırılmış kadınların rolü büyüktür. ${ }^{142}$ İslam, emirlerini kadınlar ve erkekler için ayrı ayrı vermemekle birlikte özellikle ilim tahsili konusundaki emrinde erkekleri de kadınları da aynı seviyede muhatap alır. ${ }^{143}$ İslamî yeniden doğuş, bireyin ve toplumun ilk eğiticileri olan Müslüman kadın için çok şey yapmalıdır. Bunun karşıllığında eğitimli ve şuurlu bir Müslüman kadın da aldığı sorumluluk gereği Müslüman bireyin ve toplumun yeniden inşasında çok fazla görev almalıdır. Aliya, Müslüman toplumunun yeniden dirilişi konusunda aktif rol alabileceğini düşündüğü kadınların eğitimi konusunda şu açıklamayı yapar:

"Müslüman toplumun her tarafında kadının durumu yeni neslin doğal terbiyecisi ve analığına uygun olarak değişmek zorundadır. Okumamış, ihmal edilmiş ve mutsuz bir anne, Müslüman halkların yeniden doğuşunu başlatacak ve başarılı bir şekilde devam ettirecek oğul ve kızları büyütemez."144

Aliya'ya göre, kadınlar için başlatılacak eğitimler kabiliyet ve isteklerine göre her alanda yapılmalı ve sosyal hayat içerisinde rahat çalışabilecekleri imkânlar onlara verilmelidir. Aynı zamanda onları annelik konusunda eğitecek okullar da açılmalıdır. Özellikle ve öncelikle kadınların yeniden özgüvenleri artırılmalıdır. 7/24 bütün zamanını ve mesaisini çocukları ve ailesi için geçiren kişinin annelik ve hanımlık işini tanıyacak ve bu sayede ona değerli olduğu şuurunu verecek birikimi bünyesinde barındıran İslam kültürü yeniden hayat bulmalıdır. ${ }^{145}$ Kadınlar, kendilerinde bulunan annelik vasıflarının çok özel bir durum olduğunu yeniden anlamalıdırlar. Bireysel ve toplumsal hayata başarılı bir çocuk yetiştirme üzerine tekrar düşünmeleri sağlanmalıdır. Batı'dan birçok şey alınabilir; bilim ve teknolojik

\footnotetext{
141 İzzetbegoviç, Konuşmalar, 245.

142 İzzetbegoviç, Tarihe Tanıklığım, 573.

${ }^{143}$ Karaarslan, "Aliya İzzetbegoviç'in Düşüncesinde Kadın ve Aile”, 387.

144 İzzetbegoviç, İslam Deklarasyonu, 63-64.

145 İzzetbegoviç, Özgürlüğe Kaçışım: Zindandan Notlar, 85.
}

Turkish Academic Research Review - Türk Akademik Araştırmalar Dergisi 
gelişmeler konusunda Batı ile iş birliği yapılabilir. Ancak "Batı'nın neyi alınmaz?" sorusuna verilecek ilk cevap "aile yapısı alınmaz" olmalıdır. "Bazı durumlarda Avrupalı hayat tarzı, nasıl yaşanmaması gerektiğinin örneğidir."146 Çünkü aile yapımız da oradan alınacak olunursa o zaman İslam kültür ve medeniyeti diye bir şeyden söz edilemez. Müslüman toplum, Batılıların arzu ettiği gibi Batılılaşmak ve modernleşmek yerine İslamlaşmayı tercih etmelidir. Öncelikle onları bilinçli ve eğitimli hale getirmeli sonrasında ise eğitimli kadınlardan kendi değerlerine uygun bir neslin inşası için gayret talep etmelidir. ${ }^{147}$ Müslümanlar, gelişen çağda kadınlar için yeni imkânlar sunacak olan eğitim, sosyal ve siyasi haklar açısından yeni ortamlar oluşturmalıdır. Bütün bunları gerçekleştirirken modern dünyada kendisini farklı kılan ve alternatif yaşam tarzı olarak tanımlayan insanî, İslamî ve ahlâkî duruşunu da korumalıdır. "İslam, kadınlar için eğitim ve siyasi haklar sunacak ama kendi ahlakî disiplinini de muhafaza edecektir." 148

Aliya, insan ırkının ve Bosna'nın yarısının kadınlardan oluştuğunu ifade ettikten sonra bu müstesna varlıkların verilen özgürlük ve var olma savaşında en az erkekler kadar direnişe katkı sağladıklarını belirtir. Acı ve açlık çeken, ölen, her türlü hakarete uğrayan kadınlardan, kazanılan Bosna'yı yeni bir nesil doğurup inşa edebilmeleri için küçük düşürülmelerini ve kızgınlıklarını unutup kendileriyle gurur duyacakları bir davranış içerisine girmelerini ister. ${ }^{149}$ Savaş sırasında kadınlar tarafindan cesaretle ortaya konan destansı mücadelenin benzerini Bosna'nın ve İslam'ın ilerlemesi sırasında da göstermelerini bekler. "Çünkü aklımızda hep tutalım: İslam'ın ilerlemesini her türlü ilerlemeyi olduğu gibi- sakin ve teslimiyetçi kimseler değil, cesur ve itiraz (isyankâr) ruhlu kimseler gerçekleştirecektir." ${ }^{150}$ İyi eğitimli kadınların, yıkılan Bosna'nın yeniden inşası konusunda da yeni neslin doğru bir şekilde yetişmesini sağlamada da temel unsur olduğunu ifade eder. Benzer bir açıklamasında kadın-erkek fark etmeksizin tüm insanlara Bosna sevgisini, özgürlüğü, hoşgörüyü, geleneklerine ve değerlerine saygıyı öğretmeleri gerektiğinin altını çizer. ${ }^{151}$ Bunun için çalışmak ve mücadele içinde olmak elzemdir. "Kadınlar çalışmaya, faaliyete ve mücadeleye katılmalıdır. Kadınlar eğitilmelidir. Bosna'nın yıkımlardan kaldırılmasını sağlayacak, halkın nesillerini yetiştirecek ve onların doğru yola sevk edecek kimseler ancak eğitimli kadınlar olabilir."152 Aliya, İslam Konferansı Örgütü'nün 11 Aralık 1997 tarihinde yapılan bir toplantısında toplumun yarısını oluşturan kadınların eğitimsiz, okuma yazma bilme oranlarının çok düşük olduğunu ve bu halleriyle 21. yüzyılda halkları yönetecek nesli yetiştirmede yetersiz kalacaklarını beyan eder. ${ }^{153}$

Yaratılış gayesini anlamaya ve buna uygun yaşamın gerçekleşmesine etki eden, insandan insana da çok fazla değişmeyen bazı hazırlayıcı ve sürükleyici sebepler vardır. Beden ve ruhtan müteşekkil olarak yaratılan insan, anne karnına düştüğ̈̈ andan itibaren fiziksel ve ruhsal olarak şekillenmeye başlar. Kişiliğin ve karakterin oluşacağı ilk ve en etkili ortam ailedir. Çevresel faktörler olarak

146 İzzetbegoviç, İslami Yeniden Doğuşun Sorunları, 54; Çetintaş, "Aliya İzzetbegoviç’in Siyaset Felsefesi”, 44-45.

${ }^{147}$ Karaarslan, "Aliya İzzetbegoviç’in Düşüncesinde Kadın ve Aile”, 387-388.

148 Demirci, “Aliya İzzetbegoviç’in Eserlerinde Aile ve Kadın”, 380; İzzetbegoviç, Özgürlüğe Kaçışım: Zindandan Notlar, 320.

149 İzzetbegoviç, Tarihe Tanıklığım, 573.

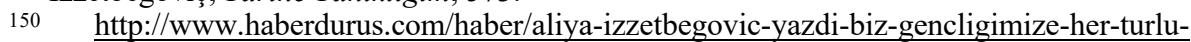
iktidara-itaat-icinde-olmasini-ogretiyoruz-35426.html (Erișim: 01.05.2020).

151 İzzetbegoviç, Tarihe Tanıklı̆̆ım, 550.

152 İzzetbegoviç, Köle Olmayacă̆

153 İzzetbegoviç, Tarihe Tanıklı̆̆ım, 414.

Turkish Academic Research Review - Türk Akademik Araştırmalar Dergisi 
niteleyeceğimiz; okul, arkadaş, sosyal ve kültürel çevre, iş ortamları, sivil toplum yapılanmaları gibi etkenler ikinci dereceden kişiyi etkiler ve nasıl bir insan olunacağına dair karar merkezleri olarak karşımıza çıkar. Bu açıdan Aliya; "Ebeveynlerin ve öğretmenlerin cehaleti ve anlayış kıtlığı yüzünden sakatlanmamış olsalardı kaç çocuk büyük adam olurdu"154 diye feryat ederken aile ortamında kadınların, çevresel etkiler içerisinde ise en önemli yere haiz olan öğretmenlerin doğru bir eğitimden geçmeleri gerektiği vurgusunu bir kez daha yapar. Geçmişten günümüze kurulan belki de kıyamete kadar kurulacak olan tüm aileler ve eğitim kurumları, sorumluluk şuuru yüksek çocuklar ve bireyler yetiştirmeyi amaçlar. Sorumluluk alanı kendisinden başlayarak, ailesinden, yakın veya uzak akrabalarına, yaşamış olduğu en küçük yerleşim biriminden ülkesine ve tüm dünya insanlığına hatta canlı cansız tüm varlıklara kadar genişleyebilecek bir alandır. Doğru bir eğitimle geliştirilmeye müsait bu şuur, insanın fitratında ve yaratılışında saklıdır. Aliya, annesinden aldığı eğitimle başladığı yaşam serüvenine devam ederken damarlarında bulunan özgürlük ruhu, onu sadece kendisi için değil, diğer insanların sorumluluğunu alan birisi olarak tarih sahnesine çıkartır ve bu uğurda inanılmaz bir çaba içerisine girmesine sebep olur. ${ }^{155}$ Sorumluluk şuurunun oluşumunda ikinciüçüncü derecede öneme sahip olan çevresel etkenler konusunda Aliya'nın hayatında görebileceğimiz çok ciddi pratikler vardır. Aliya, çevrenin gücüne dair şu yorumu yapar:

"Genetik yoluyla tüm insanların birbirlerinden farklı olduklarını ispatladık. İnsanların her ne kadar özdeş bir genetik şifresi olsa da çevre tek yumurta ikizlerini, gerçek ikizleri dahi farklı farklı şekillendirir. Dolayısıyla onlar da farklı varlıklardır” dedikten sonra "demek ki Tanrı çeşitliliği seviyor."156

İnsanın varlık, adalet, sorumluluk, birlikte yaşam, hoşgörü gibi kavramlar hakkındaki düşüncelerini çoğunlukla çevresi şekillendir. O, çocukluğundan itibaren yaygın eğitim kanallarıyla çevresinden etkilenir. Geleceğinin nasıl olacağı ve alacağı kararları etkilemesi yönüyle de Aliya kısaca "insan çevresinin ürünüdür" 157 diyerek önemli bir noktaya parmak basar. Çocukluk yıllarının geçtiği şehir ve köy hayatı, yakın ve uzak akrabalarla kurulan temas, mahalle veya geniş anlamda o yerleşim yerinde bulunan herkes Aliya'nın hayatında ciddi tesirler bırakır. ${ }^{158}$ Müslüman bir ailenin ferdi olarak her insanı yaratanından ötürü sevme kültürü ile büyümesine rağmen, kendi komşularının bencilce ve taraflı tutumları, kendileri gibi olmayanlara karşı acımasız yaklaşımları onu çok etkiler. Buna rağmen o hep birlikte yaşayabiliriz diyerek "Bosna Fikri”" diye adlandırdığı tezini sonuna kadar savunur. Savaşın en ağır koşullarında bile çevresine hep bunu tavsiye eder. ${ }^{159} \mathrm{Bu}$ fikrinde sabit olması ve bu ülküsünün gerçekleşmesi için bedeller ödeyerek mücadele etmesini sağlayan temel dinamik ailesinden aldığı ilk terbiye olan; yakınında veya uzağında çevresinde bulunan herkesle iyi geçinme kültürüdür. Çevresinin farklı etnik yapıda ve değişik dinlere sahip olan veya aynı dine mensup olmakla birlikte dini farklı seviyelerde yaşayan insanlarla kuşatılmış olmasına rağmen birlikte ve barış içerisinde yaşanabileceğinin mümkün olduğu fikri, ona çocukluğundan itibaren öğretilen en önemli değerdir. İnsanda bulunan Allah inancı ve sevgisi, O'nun yarattıklarını da kendisinden ötürü sevmeye yönlendirir. Merkezine farklılıkların zenginlik olduğu

154 İzzetbegoviç, Özgürlüğe Kaçışım: Zindandan Notlar, 320.

${ }^{155}$ Bardhi, "Aliya İzzetbegoviç-Bir Dindar ve Din Eğitimcisi”, 122-125.

156 İzzetbegoviç, Özgürlüğe Kaçışım: Zindandan Notlar, 259.

157 İzzetbegoviç, Doğu Batı Arasında İslam, 83.

158 Yorulmaz, Bilge Lider Aliya İzzetbegoviç, 38-39.

159 İzzetbegoviç, Tarihe Tanıklığım, 14-16; İzzetbegoviç, Konuşmalar, 242-244.

Turkish Academic Research Review - Türk Akademik Araştırmalar Dergisi 
yaklaşımını alan bir eğitim sisteminin bunu kavgaya yol açabilecek bir sebep olmaktan çıkartıp, bireyin ve toplumun yönlendirilmesinde avantaja dönüştürebileceği söylenebilir. Aliya, bu özellikleri ilk önce ailesinden terbiye ile alan, ardından kendi okumalarından hareketle İslam'ın böyle yaşamayı emrettiğini öğrenen ve daha sonra gereğini hayatına harfiyen uygulayan bir şahsiyet olur. Dinî eğitim açısından bir değerlendirme yapılacak olunursa, Kur'an ayetlerinin defalarca buna vurgu yaptığı ve bu konunun İslam'ın temel düsturlarından biri olduğu rahatlıkla görülebilir.

"Ey insanlar! Şüphe yok ki, biz sizi bir erkek ve bir dişiden yarattık ve birbirinizi tanımanız için sizi boylara ve kabilelere ayırdık. Allah katında en değerli olanınız, O'na karşı gelmekten en çok sakınanınızdır. Şüphesiz Allah hakkıyla bilendir, hakkıyla haberdar olandır." (Hucurat, 49/13).

Yeryüzüne halife olarak tayin edilen insan, sorumluluğunu kabul ederek ve imtihanın bir gereği olarak yaratılmışların aslî bir unsuru olur. Artık o kendisiyle birlikte yeryüzünü de imar ve inşa etme mükellefiyeti altındadır: "Şüphesiz biz emaneti göklere, yerlere ve dağlara teklif ettik de onlar onu yüklenmek istemediler, ondan çekindiler. Onu insan yüklendi. Çünkü o çok zalimdir, çok cahildir." (Ahzab, 33/72). Ahzab suresinde geçen bu ayet; insanın zalimliğinde kalıcı, bilgisizliğinde ısrarcı olmak istemiyorsa farklı eğitim süzgeçlerinden geçerek elde ettiği bilgisi, samimi imanı ve temiz ahlakıyla aldığı emanetin hakkını vererek taşımak durumunda olduğunu açıklar. Bu kadar ulvi bir emanet şuuruna sahip olan insanı inşa edecek, tek tek yetiştirip topluma faydalı hale getirecek olan kişiler en başta eğitimli ve inançlı kadınlardır.

\section{Sonuc}

Aliya, bireye dönük iç derinliğinde; ruh, kalp ve duygu açısından Doğulu, topluma dönük olan bilgiyi ve inancı hayatına tatbik etme anlamında; akıl, düşünce ve aldığı eğitim bakımından Batılı olmakla birlikte mensup olduğu din açısından ayrı bir dünyaya, yaşadığı coğrafya ve modern kültür anlamında da başka bir dünyaya mensup birisidir. Bu iki farklı durum onda avantaja dönüşmüştür. Batı'dan ve Doğudan elde ettiği birikim, bireysel ve sosyal ilişkilerinde, düşüncesinin şekillenmesinde ve gelişiminde ona hep rehberlik etmiştir. Gayesi, bir Müslüman olarak yüzyıllardır süre gelen sorunlarla boğuşan İslam dünyasına ve Müslümanlara hizmet ederken daha büyük ve derinden sorunlar yaşayan tüm insanlığa da hizmet etmektir. Aliya zor bir coğrafyada dünyaya gelmiştir. Birçok etnik grubun ve farklı dinlere, kültürlere mensup insanların birlikte yaşadığı bu topraklar onun yerine göre avantaj, yerine göre ise dezavantajlar yaşamasına sebep olmuştur. Bununla beraber bütün bu farklılıklar, Aliya'nın hemen hemen her konuda olduğu gibi -sahip olduğu olumlu bakış açısı- ona ayrışmayı, uzaklaşmayı, düşmanca yaşamayı değil, barış içerisinde birlikte yaşamayı ilke edinmesini sağlamıştır.

Aliya'nın düşüncelerinin genel karakteristiği mevcut durumdan hareketle hem İslam dünyasının hem de Batı dünyasının içinde bulunduğu kötü durumdan kurtulmak adına bireysel ve toplumsal bir değişim ve dönüşümün zorunluluğu üzerinedir. Onun çağrısı ve daveti daha çok özel bir sorumluluk duyduğu Müslümanlaradır. İnsanlığın çok yönlü kötüye gidişindeki asıl mesuliyeti genel olarak Batı'ya ve Batı'daki fikirsel gelişmelerle onun yansıması olan siyasal ve toplumsal yaşama verir. Müslümanların içinde bulundukları kötü durumu da değerlendirirken bilinçli bir şekilde bizatihi Batı'nın kendisinin mi yoksa Batılılaşma isteğinde olan veya İslam'ı belirli ve dar bir kalıba sokmak isteyen bazı

Turkish Academic Research Review - Türk Akademik Araştırmalar Dergisi 
Müslümanların mı sebep olduğu tartışmasının üzerine çıkıp tespitten ziyade çözüm önerileri getirmeyi tercih ederek yapar. Aliya, Batı'yı ve birçok açıdan geri kalmış Müslümanları soyut ve temelsiz eleştirmek yerine çözüm önerileri getirerek, Müslümanların geri kalmışlıklarından kurtulabileceklerini ve kurabilecekleri yeni bir dünya nizamı (kültür ve medeniyet) ile Batı'nın da içinde kıvrandığı sorunlarının giderilebileceğini düşünür.

O bir değişimin olması gerektiğini savunur ancak yukarıdan ve topluca veya baskıyla değil tek tek, bireysel olarak gerçekleşecek bir değişimin daha sağlkklı ve kalıcı sonuçlar doğuracağına inanır. Aliya'ya göre bu açıdan bakıldığında bireyin yeniden inşasının en kolay yapılabileceği yer aile, aile de ise bunu yapacak kişi olarak ilk ve en güzel mürebbi, eğitimci kadın olan annedir. Dolayısıyla kadının onurlu, kişilik sahibi ve eğitimli olması son derece önemlidir. Bu İslam kültürünü merkeze alan bir bakış açısıdır. Çünkü Aliya'nın düşüncelerine temel aldığı eksen İslam'dır. Bireyin ve toplumun süreklilik arz eden düzgün bir eğitimden geçmesi şarttır. Bu eğitim bilgiye dayalı bir öğretimi içermekle birlikte mevcut kültürün ve değerlerin aktarılması anlamında din eğitimini de içermektedir. Aliya'nın bu konuya dair düşüncelerini tespit edebilmek için ilk olarak doğumundan ölümüne birlikte yaşamış olduğu kendi ailesi içerisindeki kadınlarla olan ilişkilerine bakmak gerekmektedir. Aliya, kendisini takip edenlere evlat, eş, baba, dede rollerinde olduğu bu zeminde güzel örnekliklerin yaşandığı bir hayat hikayesi bırakır. Ailesindeki kadınlardan ailenin, annenin, eşin, kız çocuklarının önemini öğrendiği gibi hayatın ancak onlarla birlikte anlamlı ve yaşamaya değer olduğunu anlar. Ailesindeki kadınlarla kurmuş olduğu sıcak ve samimi ilişkilerinin boyutunu tahlil etmek Aliya'nın kadına dair düşüncelerini anlamaya ve analiz etmeye imkân verir. Eserlerinde ilk önce kadının yaratılış özelliklerinin belirginleştirilmesinin ardından şahsiyet olarak bireysel ve toplumsal konumuna vurgu yapar. Batı'yı modern dönemde kadının şahsiyet olarak aşağılanması, eş, anne ve ev hanımı olması bakımından değersizleştirilmesi üzerinden eleştiriye tabi tutar. Acımasız kuralların işlediği kapitalist dünyada kadının çalışma hayatına çekilmesi, fiziksel ve duygusal özelliklerine uygun olmayan işlerde çalıştırılması, ağır çalışma koşullarına sahip olan üretime katılmaya zorlanması veya tüketim çılgınlığında pazar haline getirilmesi Aliya açısından önemli sorunlardan birisidir.

Batı'nın içine düşmüş olduğu bu tefessüh hali, nahif olan bu varlığın birey olarak kadınlığının ve anneliğinin aşağılanmasına, aile kurumunun ve evlilik müessesesinin bozulmasıyla boşanmaların, gayri meşru ilişkilerin ve bunlardan olan çocukların artmasına sebep olmuştur. Kadınların uygunsuz şartların bulunduğu çalışma hayatına alınmasının doğurduğu en önemli sorunlardan biri, çocuk sayısının düşmesi ve mevcut çocukların bakıcılara veya kreşlere teslim edilmesine yol açmasıdır. Bir diğer sorun ise geniş aile kavramının unutulmasıyla ve yerine çekirdek aile anlayışının merkeze konulmasıyla toplumda yaşlılar diye önemli bir sorunun oluşmasıdır. $\mathrm{Bu}$ durum yaşlıların bakımevlerine bir anlamda mahkûm edilmesiyle neticelenmiştir. Aliya'ya göre Batı medeniyeti ve onun yaşam standartları mutluluk yerine mutsuzluğu ve birçok açıdan bireysel ve toplumsal bozukluğu artırmıştır. Aliya, insan olmanın ve insan kalmanın en önemli değer olduğunu önemseyen birisi olarak Batı'nın kadın anlayışını değerlendirirken komplekse kapılmamış, adil ve objektif olmaya çalışmıştır.

Aliya, Batılı fikir adamlarının İslam dünyasında bulunduğuna inandıkları ve kadın hakkında benimsenmiş olan yanlış algılarına karşı savunma yapmak yerine Müslümanların kadına dair bireysel ve toplumsal anlayışlarına yönelik eleştirilerde

Turkish Academic Research Review - Türk Akademik Araştırmalar Dergisi 
bulunur. Ancak onun eleştirileri Batılıların olumsuz yaklaşımından tamamen ayrıdır. O Müslüman kadının moderniteye ayak uyduramamasının ötesinde İslam coğrafyasında genel olarak kadınların konumunun yeteri kadar İslamî olmayışından şikâyet eder. Ona göre coğrafyadan coğrafyaya farklılık olmakla birlikte temel sorun İslam'ın insanların gündelik hayatına tam anlamıyla sirayet etmemesidir. Yüzyıllardır mevcut bulunan bu sorunların çözülmesi artık bir zarurettir. Aliya, çok eşlilik mevzusunun Batı'nın eleştirdiği kadar olmasa da sorun olarak değerlendirilen taraflarının eğitimli Müslüman kadınlar tarafından tamamen kaldırılabileceğini düşünür. Aliya, kadın-erkek arasındaki eşitlik konusunda da din olarak İslam karşısında eşitliğin mesuliyet bağlamında söz konusu olduğunu ancak toplumsal görevler ve sorumluluklar açısından bakıldığında yaratılışlarındaki farklılığın bu iki cins arasındaki eşitliği ortadan kaldırdığına inanır. Bununla birlikte bu farklılık ne erkeğin kadına ne de kadının erkeğe karşı üstün kılınması veya küçültülmesi anlamını taşımaz. Aliya, çalışma saatlerinin ve iş koşullarının ayarlanması halinde kadınların yeteneklerine uygun işlerde çalışabileceklerini savunur ve kadınların tamamen eve kapatılmasına karşı çıkar. Aliya'ya göre dinî kuralların hayata geçirilmesi, cinsel hayatta sağlıklı bir zemin oluşmasına, evlilik kurumunun daha anlamlı hale gelmesine, ölünceye kadar saygı ve sevgi içerisinde devam etmesine sebep olduğu gibi, boşanma hukuku sayesinde özellikle kadınların maruz kalabileceği mağduriyetler engellenir. Batı'da veya İslâm dünyasında birbirinden farklı da olsa kadınlara dair sorunlar vardır ve bu sorunların çözümü onların anneliğindedir. Kadının aynı zamanda bir anne olduğu veya olabileceği asla unutulmamalıdır. Günümüz dünyasında özellikle Batı'da annelik toplumsal olarak tanınmış değildir. Aliya'ya göre aile ve toplum birbirinden bağımsız olgular değildir. Aile müessesesinin manevî ve ahlaki değerinin korunması, sosyal dengenin muhafaza edilmesi açısından son derece önemlidir. Ona göre modern hayatın kadın üzerindeki olumsuz etkileri aile içerisindeki bağların kopmasına ve iletişimin neredeyse tamamen bitmesine neden olur. Ailede ebeveynler arasındaki sorunların artması eğitim ve terbiye noktasında eksik, mutsuz ve doyumsuz gençlerin çoğalmasına da sebep olur.

Aliya'nın ailesi, aile mensubu olan kadınların rollerini icra etmeleri bakımından incelendiğinde örnek bir Müslüman aile olarak nitelendirilebilir. Özellikle anne olan kadınların Müslüman şahsiyetler olarak öğrendikleri doğruları çocuklarına göstererek öğretmeleri ve gelecek nesle gurur duyacakları itibarlı bir aile geçmişi bırakmaları son derece önemlidir. Çocuklarına kulluk bilincini, uğruna ölebilecekleri vatan ve birlikte yaşayabilecekleri millet sevgisini ilk öğretenler aile büyükleri olan kadınlardır. Kadın, verimliliğin, doğumun, yeni nesillerle geleceğin şekillenmesinin adı ve doğrudan kurucusudur. $O$, hem yönetmen hem aktör olduğu gibi eğitimle elde edeceği bilgi, birikim ve bilinçle de bu süreci kurgulayan bir senaristtir. Gelecek nesillerin inşasında annelere önemli roller yükleyen Aliya, tüm annelerin her açıdan eğitimli olması gerektiğine inanır. Ailenin temel direği olan annenin dinî açıdan bilgili ve bilinçli olması, çocuğun özellikle dinî eğitim alması ve mevcut kültürün devam ettirilmesi açısından son derece önemlidir. Ailede kadın, insanlığın meşru zeminde çoğalmasını sağladığı gibi düzgün bir şekilde eğitilmesini de gerçekleştiren ilk ve en doğru kişidir. Bu direğin sarsılmaması, annelerden bu rolün alınmaması insanın kendi eliyle oluşturabileceği felaketlerin engellenmesi açısından mühimdir. Aliya'ya göre her insanın doğumundan itibaren ilk eğiticisi annedir. Dolayısıyla erkekler gibi kadın olarak annelere de her açıdan saygı duyulmalı ve çok iyi bir eğitim almaları sağlanmalıdır. Kadınlar için başlatılacak eğitimler kabiliyet ve isteklerine göre her alanda yapılmalı ve özellikle annelik

Turkish Academic Research Review - Türk Akademik Araştırmalar Dergisi 
konusunda eğitilmeleri ihmal edilmemelidir. İslami yeniden doğuşun gerçekleşmesi için gayret eden insanlar, bireyin ve toplumun ilk eğiticileri olan Müslüman kadınların yeniden onurlarını kazanmaları adına çok şey yapmalıdırlar. Onurlarını yeniden kazanan eğitimli ve şuurlu Müslüman kadınlar da kendilerinden beklenen fedakarlığ 1 göstererek Müslüman bireyin ve toplumun yeniden inşasında çok fazla görev almalıdırlar. Gençliğin yetiştirilmesinde bastırılmamış, eğitim almış, gerektiğinde sosyal hayat içerisinde kabiliyetine göre farklı görevler üstlenmiş kadınların rolü büyüktür. Müslümanlar, Batılıların istediği gibi modernleşmek yerine İslamlaşmayı tercih etmelidir. Öncelikle kadınlar; bilinçli ve eğitimli hale getirilmeli, sonrasında ise eğitimli kadınlardan kendi değerlerine uygun bir neslin inşası için çaba istenmelidir. Müslümanlar gelişen çağda kadınlar için yeni imkânlar sunacak olan eğitim, sosyal ve siyasi haklar açısından yeni ortamlar oluşturmalıdır. Kadınlar modern dünyada kendilerini farklı kılan ve alternatif yaşam tarzı olarak tanımlayan insanî, İslamî ve ahlâkî duruşlarını da korumalıdırlar. Ona göre eğitim almamış, kendi iç dünyalarına mahkûm edilmiş mutsuz kadınlar, Müslümanların yeniden dirilmesini başlatacak ve başarılı bir şekilde devam ettirecek çocukları büyütemez.

\section{Kaynakça}

Ademi, Rahman-Orçan, Mustafa, "İzzetbegoviç'in Hapishane Arkadaşı ve Dostu Hasan Çengiç’le Konuşma”, Hece Ayllk Edebiyat Dergisi, Çev. Cenana Braçkoviç, S.229, 2016.

Akçay, Musab, “Aliya İzzetbegoviç ve Düşünce Dünyası”, Yüksek Lisans Tezi, Atatürk Üniversitesi Sosyal Bilimler Enstitüsü, Erzurum, 2016.

Akın, Mahmut Hakkı, "Aliya İzzetbegoviç'in Entelektüel Mirası", Uluslararası Aliya İzzetbegoviç Sempozyumu (11-12 Ekim 2008), Ed. Ömer Hakan Özalp-Kenan Gültürk, Etkin Ajans, İstanbul, 2010.

Akın, Mahmut Hakkı - Karaarslan, Faruk, Aliya İzzetbegoviç: Özgürlük Mücadelesi ve İslâm Düşünürü, 2. Bsk., Pınar Yayınları, İstanbul, 2015.

Aktaş, Hamza, “Aliya İzzetbegoviç’in Düşüncesinde Ahlak-Terbiye İlişkisi”, I. Uluslararası Bir Bilge Bir Ülke Sempozyumu Bildiriler Kitabı (3-5 Ekim 2018), Ed. Mümin Hakkıoğlu vd., Gümüşhane Üniversitesi Yayınları, Gümüşhane, 2018. 2014.

Aktaş, Ümit, Çağımızın Tanıkları, Metamorfoz Yayıncılık, 2. Bsk., İstanbul,

Aktay, Yasin, “Açılış Konuşması”, Uluslararası Aliya İzzetbegoviç Sетроzуити (11-12 Ekim 2008), Ed. Ömer Hakan Özalp-Kenan Gültürk, Etkin Ajans, İstanbul, 2010.

Aslan, Emre Ş. - Selvi, Özgür, "Bir Marka Kişilik Olarak Aliya İzzetbegoviç'in Türk Toplumundaki Algısı", I. Uluslararası Bir Bilge Bir Ülke Seтроzуити Bildiriler Kitabı (3-5 Ekim 2018), Ed. Mümin Hakkığlu vd., Gümüşhane Üniversitesi Yayınları, Gümüşhane, 2018.

Ataş, Mehmet, "Entelektüel Lider Bağlamında Aliya İzzetbegoviç Üzerine Nitel Bir İnceleme", Yüksek Lisans Tezi, Sakarya Üniversitesi Sosyal Bilimler Enstitüsü, Sakarya, 2016.

Turkish Academic Research Review - Türk Akademik Araştırmalar Dergisi 
Aygün, Aykut, “Aliya İzzetbegoviç’te Din ve Siyaset”, Yüksek Lisans Tezi, Necmettin Erbakan Üniversitesi Sosyal Bilimler Enstitüsü, Konya, 2017.

Bal, Hüseyin, “Aliya İzzetbegoviç ve Bilgeliğin Tezahürleri”, Sosyal Araştırmalar ve Davranış Bilimleri Dergisi, C.5, S.9, 2019.

Balc1, Mustafa, “İzzetbegoviç'in Dostu Fatih Ali Hasaneyn ile Konuşma”, Trc. Elvan Büşra Yenigün, Hece Aylık Edebiyat Dergisi, S.229, 2016.

Bardhi, İsmail, “Aliya İzzetbegoviç-Bir Dindar ve Din Eğitimcisi”, Uluslararası Aliya İzzetbegoviç Sempozyumu (11-12 Ekim 2008), Ed. Ömer Hakan Özalp-Kenan Gültürk, Etkin Ajans, İstanbul, 2010.

Bayram, Meryem, “Aliya İzzetbegoviç’in İslamlaşma Anlayışı”, Yüksek Lisans Tezi, Necmettin Erbakan Üniversitesi Sosyal Bilimler Enstitüsü, Konya, 2019.

Çetin, Yalçın, "Bilge Kral” ve "Müslüman Batı Aydını” Şeklinde Yaratılmış İmajların Aliya İzzetbegoviç’in Eserleri, Kişiliği ve Yaşantısı Üzerinden Geçerliliğinin Kavramsal Soruşturması Üzerine”, 5.Uluslararası Kültür ve Medeniyet Kongresi Tam Metin Kitabı (12-14 Nisan 2019), İksad Yayınevi, Hatay, 2019.

Çetintaş, Oya, “Aliya İzzetbegoviç’in Siyaset Felsefesi”, Yüksek Lisans Tezi, Uşak Üniversitesi Sosyal Bilimler Enstitüsü, Uşak, 2018.

Dalkılıç, Melike, "Bir Çağdaş İslam Düşünürü Olarak Aliya İzzetbegoviç", Yüksek Lisans Tezi, Necmettin Erbakan Üniversitesi Sosyal Bilimler Enstitüsü, Konya, 2019.

Demirci, İbrahim, “Aliya İzzetbegoviç’in Hayatında ve Eserlerinde Aile ve Kadın”, Hece Aylık Edebiyat Dergisi, S.229, 2016.

Dölek, İlbey, “Aliya İzzetbegoviç’in Eserlerinde Batı, Hristiyanlık ve Hz. İsa", Mardin Artuklu Uluslararası Multıdisipliner Çalışmalar Kongresi Sosyal Bilimler Tam Metin Kitabı (19-21 Nisan 2019), Ed. Hasan Çiftçi, Yasemin Ağaoğlu, İksad Yayınevi, Mardin, 2019.

Eliaçık, R. İhsan, Aliya İzzetbegoviç Yenilikçi Müslüman Düşünürler Dizisi 2, 2. Bsk., Tekin Yayınevi, İstanbul, 2016.

Gümüş, Zümrüt, "Bosna Hersek Savaşı ve Uluslararası İlişkilerdeki Yeri”, Yüksek Lisans Tezi, Cumhuriyet Üniversitesi Sosyal Bilimler Enstitüsü, Sivas, 2005.

Gündüz, Süleyman, "Sade ve Bilge İnsan Aliya İzzetbegoviç”, Hece Aylık Edebiyat Dergisi, S.229, 2016.

Gürsu, Orhan, "Değișen Dünyada Aile ve Psikolojik Problemler", Dicle Üniversitesi Ilahiyat Fakültesi Dergisi, C.17, S.1, 2015.

İsakoviç, Zehrudin, “Aliya İzzetbegoviç 1925-2003 Biyografi”, Hece Aylık Edebiyat Dergisi, S.229, 2016.

İzzetbegoviç, Aliya, Doğu Batı Arasında İslam, Trc. Salih Şaban, 17. Bsk., Klasik Yayınları, İstanbul, 2017.

İzzetbegoviç, Aliya, İslam Deklarasyonu, Trc. Rahman Âdemi, 35. Bsk., Fide Yayınları, İstanbul, 2017.

Turkish Academic Research Review - Türk Akademik Araştırmalar Dergisi 
İzzetbegoviç, Aliya, İslami Yeniden Doğuşun Sorunlarl, Trc. Rahman Âdemi, 32. Bsk., Fide Yayınları, İstanbul, 2017.

İzzetbegoviç, Aliya, Kendi Kaleminden Aliya İzzetbegoviç: II. Endülüs Soykırımına Geçit Vermeyen Bilge Adam, Trc. Alev Erkilet vd., Dergâh Ofset Yayınları, İstanbul, 2003.

İzzetbegoviç, Aliya, Konuşmalar, Trc. Fatmanur Altun-Rıfat Ahmetoğlu, 23. Bsk., Klasik Yayınları, İstanbul, 2017.

İzzetbegoviç, Aliya, Köle Olmayacağız, Trc. Rahman Ademi, 27. Bsk., Fide Yayınları, İstanbul, 2017.

İzzetbegoviç, Aliya, Özgürlüğe Kaçışım: Zindandan Notlar, Trc. Hasan Tuncay Başoğlu, 24. Bsk., Klasik Yayınları, İstanbul, 2017.

İzzetbegoviç, Aliya, Tarihe Tanıklığım, Trc. Alev Erkilet, vd., 16. Bsk., Klasik Yayınevi, İstanbul, 2016.

Karaarslan, Faruk, "Aliya İzzetbegoviç'in Düşüncesinde Kadın ve Aile", Hece Ayllk Edebiyat Dergisi, S.229, 2016.

Karaarslan, Faruk, "Entelektüel Üzerine Bir Çalışma: Aliya İzzetbegoviç Örneği”, Yüksek Lisans Tezi, Selçuk Üniversitesi, Sosyal Bilimler Enstitüsü, Konya, 2010.

Kıral, Bilgen, "Nitel Bir Veri Analizi Yöntemi Olarak Doküman Analizi”, Siirt Üniversitesi Sosyal Bilimler Enstitüsü Dergisi, S.15, 2020.

Kızılabdullah, Yıldız, "Kavramsal Çerçeve: Eğitim, Öğretim ve Din”, Din Eğitimi, Ed. Recai Doğan-Remziye Ege, Grafiker Yayınları, Ankara, 2015.

Koçoğlu, Bülent, "Aliya İzzetbegoviç'in Eğitim, Din Eğitim ve Öğretimi Görüşleri”, Yüksek Lisans Tezi, Akdeniz Üniversitesi Sosyal Bilimler Enstitüsü, Antalya, 2019.

Kodal, Tahir, "Bosna-Hersek'in Bağımsızlığını Kazanması ve Türkiye (1990-1992)", Atatürk Araştırma Merkezi Dergisi, 34/2, 2018.

Limon, Aynur, "Siyasi Bir Lider Olarak Aliya İzzetbegoviç", Yüksek Lisans Tezi, Afyon Kocatepe Üniversitesi Sosyal Bilimler Enstitüsü, Afyonkarahisar, 2019.

Orçan, Mustafa, "Ufuk Soran ile Bir Bosna Gazisinin İlginç Anıları", Hece Aylık Edebiyat Dergisi, S.229, 2016.

Özdemir, Musa, "Aliya İzzetbegoviç Düşüncesinde Üçüncü Yol Kavramı ve Felsefi Temelleri”, Yüksek Lisans Tezi, Gazi Üniversitesi Sosyal Bilimler Enstitüsü, Ankara, 2014.

Özel, İsmet, $\ddot{U} c ̧$ Zor Mesele, 10. Bsk., Tiyo Yayınları, İstanbul, 2019.

Öztürk, Hacer, "Yıldızın Altında Yatan Adam", Hece Aylık Edebiyat Dergisi, S.229, 2016

Öztürk, Niyazi, "Nurettin Topçu ve Aliya İzzetbegoviç’te Din Anlayıșı", Yüksek Lisans Tezi, Tokat Gaziosmanpaşa Üniversitesi Sosyal Bilimler Enstitüsü, Tokat, 2019.

Turkish Academic Research Review - Türk Akademik Araştırmalar Dergisi 
Pulat, Tunç, “Bosna-Hersek’te Devlet İnşa Süreci: 1996-2013 Dayton Antlaşması Sonrasında Bosna-Hersek", Yüksek Lisans Tezi, Atılım Üniversitesi Sosyal Bilimler Enstitüsü, Ankara, 2015.

Sevil, Muharrem, "Kadeh Bağını Kıran "Dedo", Uluslararası Aliya İzetbegoviç Sempozyumu (11-12 Ekim 2008), Ed. Ömer Hakan Özalp-Kenan Gültürk, Etkin Ajans, İstanbul, 2010.

Soysal, Abdullah, "Entelektüel Liderliği ile Model İnsan: Aliya İzzetbegoviç”, Uluslararası Íslam ve Model İnsan Sempozyumu (26-27 Nisan 2018), Ed. M. Akif Özdoğan vd., Kahramanmaraş Büyükşehir Belediyesi Yayınları, Kahramanmaraş, 2018.

Şafak, Yasin, “Bosna Savaşı ve Yugoslavya'nın Parçalanması”, Yüksek Lisans Tezi, Kadir Has Üniversitesi Sosyal Bilimler Enstitüsü, İstanbul, 2010.

Tekin, Cemile, Halilovic, 'Boşnaklar'ın Bosna-Hersek Devleti'ni Kurma Mücadelesi ve Alija Izetbegovic", Türk- Íslam Medeniyeti Akademik Araştırmalar Dergisi, S.14, 2012.

Uğurlu, Yaşar, “Doğu'nun Çocuğu Batı'nın Münevveri Aliya İzzetbegoviç”, Hece Ayllk Edebiyat Dergisi, S.229, 2016.

Yorulmaz, Hüseyin, "İzzetbegoviç Ailesinin Bilinmeyenleri”, Hece Aylık Edebiyat Dergisi, S.229, 2016. 2015.

Yorulmaz, Hüseyin, Bilge Lider Aliya İzzetbegoviç, Hat Yayınları, İstanbul,

\section{İnternet Kaynakları}

http://www.mm.co.ba/index.php/tr/oezgecmisleri/879-bilge-kral-hayatagoezlerini-yumdu (Erişim: 05.05.2020).

https:/www.aa.com.tr/tr/dunya/bosna-hersek-bagimsizlik-gununukutluyor/178309 (Erişim: 15.05.2020).

https://www.dunyabizim.com/soylesi/serif-petkovic-ile-aliya-izzetbegovicedair-konustuk-h24995.html (Erişim: 17.05.2020).

https://www.dunyabulteni.net/kultur-sanat/sadece-aliya-h337468.html (Erişim: 01.05.2020).

https://adaletzemini.org/19-kasim-2017-dogu-ve-bati-arasinda-mucahid-birbilge-aliya-izzetbegovic-1925-2003/(Erişim: 01.05.2020).

http://www.irsadgenclik.org/bilge-kral-aliya-izzet-begovic/ (Erişim: 05.05.2020).

http://www.sanalbasin.com/suleyman-gunduz-yazdi-bir-kitle-heykeltirasialija-izetbegovic-15880526/ (Erişim: 05.05.2020).

https://suffagah.com/aliya-izzetbegovicin-kadin-istihdamina-yonelik-5beyani (Erişim: 01.05.2020).

https://www.dunyabizim.com/polemik/aliya-kadina-nasil-bakiyorduh379.html (Erişim: 01.05.2020).

http://www.irsadgenclik.org/bilge-kral-aliya-izzet-begovic/ $\quad$ (Erişim: 05.05.2020).

Turkish Academic Research Review - Türk Akademik Araştırmalar Dergisi 
https://suffagah.com/aliya-izzetbegovicin-kadin-istihdamina-yonelik-5beyani (Erişim: 01.05.2020).

http://www.irsadgenclik.org/bilge-kral-aliya-izzet-begovic/ $\quad$ (Erişim: 05.05.2020).

https://suffagah.com/aliya-izzetbegovicin-kadin-istihdamina-yonelik-5beyani (Erişim: 01.05.2020).

https://www.tyb.org.tr/20-yuzyilda-insanligin-onurunu-kurtaran-liderdiraliya-18888yy.htm (Erişim: 17.05.2020).

https://www.yenisafak.com/hayat/bosna-bilge-lider-aliyayi-ozlemle-aniyor2550485 (Erişim: 17.05.2020).

https://kuran.diyanet.gov.tr/tefsir/ $\mathrm{N} \% \mathrm{C} 3 \% \mathrm{BBr}$-suresi/2822/31-ayet-tefsiri (Erişim:07.06.2020).

https://islamansiklopedisi.org.tr/talak (Erişim: 07.06.2020).

https://islamansiklopedisi.org.tr/hitti-philip-khuri (Erişim: 07.06.2020).

http://www.sanalbasin.com/suleyman-gunduz-yazdi-bir-kitle-heykeltirasialija-izetbegovic-15880526/ (Erişim: 05.05.2020).

https://fethigungor.net/dirilis-postasi/aliyayi-fikriyatini-davasini-anlamak/ (Erişim: 09.05.2020).

http://www.haberdurus.com/haber/aliya-izzetbegovic-yazdi-bizgencligimize-her-turlu-iktidara-itaat-icinde-olmasini-ogretiyoruz-35426.html (Erişim: 01.05.2020).

Turkish Academic Research Review - Türk Akademik Araştırmalar Dergisi 